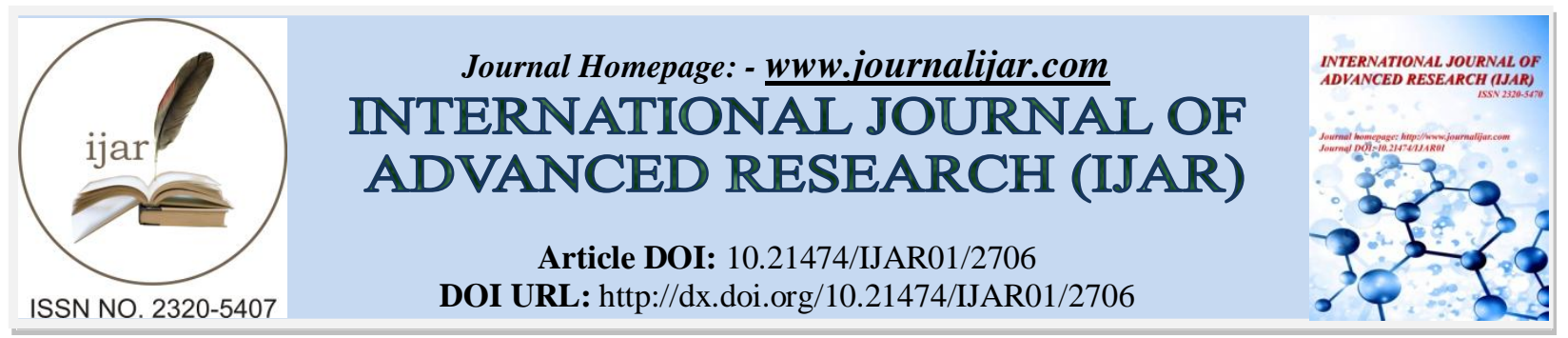

RESEARCH ARTICLE

\title{
GEOMORPHOLOGY \& SEDIMENTATION OF THE AREA AROUND HOMINID LOCALITY HATHNORA NARMADA RIFT VALLEY CENTRAL INDIA.
}

\section{Dr. A. A. Khan and Dr. Maria Aziz.}

1. Ex. Director, Geological Survey of India, Director Rajeev Gandhi Proudyogiki Mahavidyalaya, Bhopal462042, M.P India.

2. Director, Pri-Med Care Lewisville Texas 75067 USA.

\section{Manuscript Info}

Manuscript History

Received: 31 October 2016

Final Accepted: 01 December 2016

Published: December 2016

\section{Abstract}

Narmada River originates at Amarkantak at an elevation of about $1057 \mathrm{~m}$ above m.s.l. It descendeds from the mountainous tract traversing over a distance of $1280 \mathrm{~km}$ across the middle of the Indian sub-continent to join the Gulf of Cambay, near Baroda in Gujrat state. The area of study around Homonid locality Hathnora forms the part of central sector of Narmada, it is bound by Vindhyachal in the north and Satpura range to the south; the area in between these two upland is found to be ideal locus of sedimentation as witnessed by the presence of Quaternary landscape and multicyclic sequence of Quaternary terraces in the valley.The general elevation of Narmada alluvial plain varies between 00.00 to $65.00 \mathrm{~m}$ in lower Narmada and 65.00 to $95.00 \mathrm{~m}$ in upper Narmada valley above the sea level. The general gradient of this plain in this stretch is about $1 \mathrm{~m} / \mathrm{km}$ towards west.

The Narmada conspicuously has straight course is controlled by ENE_WSW to E_W lineament, is bounded by Vindhyan in the north and Satpura in the south it is exposed the repeated post erisional and depositional activities and subjected to anisotropic and asymmetric tectonic dislocation which has culminated diversified units and region which further undergone to process of tectonic evolution and chiseling of terrain by dynamic erosional and depositional activity resulting in and reshaping the terrain into various morphogenetic units and land form elements, re-configuration of drainage, topography, physiographic, erosional platform, planation surfaces, denudation ridges, structural units linear valleys, strike hills, valley gapes, escarpments and river terraces. The cumulative dynamics of structural deform, rinsing and sinking platform of Narmada has also manifested concealed cyclic mechanism of tectonics, seiesmicity, neosiesmic events and in surface manifestation. In addition the valley gapes and valley trenches provided ideal sites and platform for accumulation\&sedimentation.

The Narmada Rift valley formed a linear trench in the middle of Indian subcontinent was an ideal locus for accumulation of sediments.The rift trench is intruded by the dolerite and other mafic and siliceous dykes and sills along lineaments in different phases of

Corresponding Author:- Dr. A. A. Khan. 
Tectonic deformation. The Quaternary sedimentation incepting from glacial activity, followed by fluvio-glacial, lacustrine and fluvial phase within the rinsing and sinking environment, block, faulting, uplifting, isolated domal up- lift, Neogene rifting, Quaternary sedimentation, rift-bound Pliocene-Pleistocene rifting and volcanic activity specifically during glacial and fluvio-glacial phase are major component of the Quaternary period and tectonic processes of the Narmada Rift System which forms the base of quaternary deposits .

The Quaternary events of the Narmada portys three prominent terraces and two sub terraces which are designated NT1 to NT3 and sub terraces NT2-A is NT2-B, NT2 B, besides NT2-C, NT3-A \& NT3-B besides NT-0 in the valley. They have been designed $\mathrm{NT}_{\mathrm{O}}$ to NT3, ( 280 to $400 \mathrm{~m}$ ), $\mathrm{NT}_{\mathrm{O}}$ being the low level terrace above the present-day course of the river, $\mathrm{NT}_{1}$-the younger terrace both of cyclic ad o cyclic nature. The $\mathrm{NT}_{3}$ terrace occurs as elongated strip and isolated caps and lenses along the margin of valley flanks has divergent relative disposition. These land forms indicate vigorous and abrupt incision of valley floor due to relatively \& repaid uplift of watershed area during Upper Pleistocene time. The NT1to $\mathrm{NT}_{2}$ are the major depositional terrace and have both convergent $\&$ divergent mutual disposition with other terrace. These terraces further downstream have matched equivalents along the valley flanks, whereas in the up stream section the matched equivalents are rare. The conspicuous divergent relation of these terraces the valley reveals successive uplift of catchments area and consequential incision of valley floor and adjustment of base level of Narmada during Upper Pleistocene time.

The sequence of quaternary dposits depicts cyclic transitional environmental of the rift basins are caused by tectonic activities (uplift and subsidence), changes in relief, and climatic variations. The climatic changes in uplift, coupled with block faulting, rinsing and sinking platform, created basins unstable platform for the accumulations of thick lacustrine and fluvial sediments sequences with terrestrial and aquatic fossils. The evidence of the effects of tectonics on fauna and flora are distinct and its signatures on dislocation and concealing of fossiliferous horizons are uncontrolled and ill defined in the ecosystem in the valley during the PliocenePleistocene periods. The boulder conglomerate which yielded the skull cap of Homo eructs in Narmada rift from Hathnora Sonakia (1984) remainedonly discovery of hominid fossil in last two and half decade due inconsistency and concealed nature of fosilifrous horizon due faulting, and subsidence of Quaternary blanket of Narmada rift system as such researcher and scientist failed to add any further knowledge to hominid discovery.in Narmada valley...

Copy Right, IJAR, 2016,. All rights reserved.

\section{Introduction:-}

Narmada River originates at Amarkantak at an elevation of about $1057 \mathrm{~m}$ above m.s.l. it descendeds from the mountainous tract traversing over a distance of $1280 \mathrm{~km}$ across the middle of the Indian sub-continent to join the Gulf of Cambay, near Baroda in Gujarat state. The river course of Narmada is conspicuously straight, controlled by E-W lineament. It decends down the mountaineous tract through deep and steep gourges in straight sinuous to meandering pattern with average sinuosity index of 1.38 , which at places exceedes 1.55 for some selected segments of Narmada channel. It almost flows E-W along the Lineament over a length of 1300 Kilometers across the middle of Indian sub-continent to debouch into the Gulf of Cambay in the Arabian Sea. The area of study around Homonid locality Hathnora forms the part of central sector of Narmada, is bound by Vindhyachal in the north and Satpura range to the south; the area in between these two upland is found to be ideal locus of sedimentation as witnessed by 
the presence of multicyclic sequence of Quaternary terraces in the valley on the surface and possess thick sequence of concealled quaternary sediments up to the depth of $320 \mathrm{~m}$ as witnessed by bore hole logs and data of state and Fadral agencies drilled under various projects Khan et.al (2012) Khan et.al (2013)Khan et.al (2014)Khan et.al (2015)Khan et.al (2016)Khan et.al (2016).

\section{Previous Work:-}

The Quaternary deposits of Narmada have been studied in detailed in last three decade and lithostratigraphy of Narmada valley has been updated (Khan 1984, Khan \& Benarjee 1984, Khan \& Rahate 1990-91-90 Khan \& Sonakia 1992, Khan \&et al 1991, Rahate \& Khan 1985, Khan et al. 1991, Khan 1991, Khan et al. 1992, Yadav \& Khan 1996. The Narmada valley embodied almost whole of the Quaternary deposits time span from the lower Pleistocene to Holocene (Khan \& Sonakia (1992). Khan (1912), Khan (2012), Khan et.al (2013) Khan et.al (2014), Khan ( 2015), Khan et.al (2015) Khan etal (2015) .The results of sedimentological studies Khan ( 2015), quartz grain morphology, Paleosole studyKhan (2014), in recent years detailed aspects of heavy mineral assemblage, sedimentry structures,Quatenary tectonics \& sedimentation, geomorphphic evolution have been attemeptedof Quaternary column of Hominid locality in central sector of Narmada, revealed the presence of complete sequence of quaternary sediments in Narmada rock basin viz Glacial, fluvio-glacial ad fluvial domain wheras the boulder conglomerate which has yielded human skull which is of fluvio-glacial origin Khan \& Sonakia (1991)

\section{Present work:-}

The present work is telefocus to study the varios aspsects of geomorphology and georphphic veolution, Quaternary tectonics and sedimentation of the area around Hominid locality Hathnora in the central sector of Narmada valley. The area studied is about $4000 \mathrm{sq.km}$, is occupied by thick Quaternary deposits, it is estimated to be about $320 \mathrm{~m}$ thick the merits of bore hole data of ETO, CGWB and GSI, represent various domain of sedimentation. It is found to be ideal locus of sediment accumulation and Quaternary sedimentation in central India as witnessed by multi-cyclic sequence of Quaternary terraces in the valley.

The area has been posed to the repeated post erosional \& depositional activities and subjected to anisotropic and asymmetric tectonic dislocation which has culminated diversified manifestation, which further undergone to process of tectonic evolution and chiseling of rift valley by dynamic erosional and depositional activity resulting in reshaping of the terrain into various multi morphogenetic illustration and reorganization of units and land form element, sequential and renewed configuration of drainage, topography, physiography,plantation surfaces, denudation ridges, structural linear valleys, strike hills, valley gapes, escarpments and river terraces. The cumulative concealed dynamics and structural deformation of rinsing and sinking platform of Narmada, hidden cyclic mechanism of tectonics, geothermic, seismicity and neotectonics has illustrated various signatures and imprints on landscape in the valley. The landscape and valley architech provided ideal sites and platform for sedimentation has been collectively studied.In addtion to the landscape profile of the area, drainage configuration river terrace, basin boundaries Quaternary sedimentation and configuration of land form elements have been studied, and correlated with geomorphic events, erosional cycles neotectonics events, paleosoles, sedimentation, tephra events and occurrencesat different levels in increasing antiquity (Plate No_1 \& 2).

\section{Narmada Rift Valley:-}

In Central India SONATA LINEAMENT ZONE embodies the two Quaternary basins of tectonic origin on the two margins of Satpura Crustal Block Namada \& Tapti. The associated Narmada South (Satpura North) fault and Satpura South Fault marking the two hinges of the Satpura block are fundamental in nature and extend to Moho level. The Narmada Quaternary basin in the north and Tapti-Purna basin in the south are flanking Satpura.The Satpura Range, trending ENE-WSW forms a prominent morph tectonic unit in the area bound by Lat. $20^{\circ} 43^{\prime} \mathrm{N} \&$ $23^{\circ} 30^{\prime} \mathrm{N}$ and longitudes $73^{\circ} 52^{\prime} \mathrm{E}$ and $81^{\circ} 30^{\prime} \mathrm{E}$, between Rajpipla, (Gujarat) in the West and Maikal Ranges (Madhya Pradesh) in the east. The Satpura block is flanked in the North by Collinear Valleys of Narmada and Son and in the South by Tapti-Purna; Kanhan, Pench and Wainganga rivers flow across the southern slopes in the eastern part.

The area studied tectonically encompasses two crustal provinces of Central India Shield, namely, the Northern Crustal Province (NCP) and the Southern Crustal Province (SCP (Acharyya and Roy, 1998; Roy, 1988). The two provinces are separated by a crustal level shear zone, referred as Central Indian Suture (CIS Jain et al. 1995). The southern part of the NCP, containing the Satpura and son Narmada (SONA) valley geographic domain, is known as Central Indian Tectonic Zone (CITZ; Radhakrishna and the CITZ are marked by Narmada North Fault (NNF) in the north and CIS in the south (Acharyya, 1999). 
The area studied tectonically encompasses two crustal provinces of Central India Shield, namely, the Northern Crustal Province (NCP) and the Southern Crustal Province (SCP (Acharyya and Roy, 1998; Roy, 1988). The two provinces are separated by a crustal level shear zone, referred as Central Indian Suture (CIS Jain et al. 1995). The southern part of the NCP, containing the Satpura and son Narmada (SONA) valley geographic domain, is known as Central Indian Tectonic Zone (CITZ; Radhakrishna and the CITZ are marked by Narmada North Fault (NNF) in the north and CIS in the south (Acharyya, 1999).

The study of tectonic set up of Narmada valley, surface manifestation and geo-physical data shows that the SonNarmada and Tapti lineament together represent an intraplate rift with a central (Satpura Block) horst bounded on either side by grabens: the Narmada graben on the north and the Tapti graben to the south (Mishra et al, 1999).

The catchment area of the river, bordered by the Satpura and Vindhya Mountain Ranges, stretches over a territory of $98,796 \mathrm{~km} 2(38,145.3 \mathrm{sq} \mathrm{mi})$. It is situated between longitudes $72^{\circ} 32^{\prime}$ and $81^{\circ} 45^{\prime}$ east and latitudes $21^{\circ} 20^{\prime}$ to $23^{\circ} 45^{\prime}$ north, on the northern edge of the Deccan Plateau. The catchment area encompasses important regions in Madhya Pradesh, Gujarat, and Maharashtra.

The Quaternary tract of Narmada basin covers an area of about 17950 sq. km starting from west of Jabalpur $\left(23^{0} 07^{0} 790530\right)$ to east of Harda $\left(22^{0} 29^{\prime} ; 76^{\circ} 58^{\prime}\right)$, and Gureshwar and Bharouche section in Gujarat state for a distance of about $1320 \mathrm{~km}$. It is found to be ideal locus of Quaternary sedimentation in Central India as witness by multi-cyclic sequence of Quaternary terraces in the valley. The general elevation of Narmada alluvial plain varies between 265.7 and $274.3 \mathrm{~m}$ above the sea level. The general gradient of this plain in this stretch is about $1 \mathrm{~m} / \mathrm{Km}$ towards West.

The principal tributaries of Narmada River are Sher Sakkar Dudhi inTawa and Ganjal in, Hiran\& Gaur. The Man, Karjan, Madhumati, Heran and Orsang, Amravati Narmada valley originate from the Satpura and Vidhyan hills from south and north of the trunk channel the most of these tributaries have short and precipitous course after they debouch from the hills. The area of sub basin of these tributatries is occupied by thick Quaternary sedimentsareclassified as older and younger alluvium on the basis of lithology sedimentological characters environments of sedimentation geological breaks. The banket of quaternary sediments of Sher Sakkar Dudhi inTawa and Ganjal, Hiran\& Gaur.in Narmada valleyis chiseled in to two terraces besides present day flood plain. These terraces are designated as ST1 to ST2; SHT1 to SHT2, TT1 to TT2, and DT1 to DT2 resoectively.The landsacpe is entrenched and cut accross deep in quaternary blanket in to steeped sequence of terraces. These terraces are time equvalent to each other and have developed simultanoiosly during the same events. The incised blanket exposes lateral sedquence of quaternary sediment which depict hidden strata, unseen relict exposures of older deposits and signatures and imprints of neotectonisam.

The Narmada Rift valley formed a linear trench in the middle of Indian subcontinent was an ideal locus for accumulation of sediments. The rift trench is intruded by the dolerite and other mafic and siliceous dykes and sills along lineaments in different phases of tectonic deformation. The Quaternary sedimentation incepting from glacial activity, followed by fluvio-glacial, lacustrine and fluvial phase within the rinsing and sinking environment, block faulting and segmental and linear displacement and dislocation, uplifting and isolated domal up- lift, Neogene rifting and Quaternary sedimentation and rift-bound Pliocene-Pleistocene rifting and volcanic activity specifically during glacial and fluvio-glacial phase are major component of the Quaternary period and tectonic processes of the Narmada Rift System which form the base of quaternary deposits.

The Quaternary events of the Narmada portys three prominent terraces and two sub terraces which are designated NT1 to NT3 and sub terraces NT2-A is NT2-B, NT2 B, besides NT2-C, NT3-A \& NT3-B besides NT-0 in increasing order of antiquity. The terraces are described in detail separately. These are both erosional and depositional terraces and confined at an elevation of, between $280 \mathrm{~m}$ to $310-315$. The NT1 is being the youngest terrace and NT3- B it is being the oldest terrace identified in the valley. The realative disposition of these teraces is shown in the (Table No_2 to _7).

The Narmada has in the area under study has sculptured the alluvial tract into stepped sequence forming four alluvial terraces along its course. These are designated as NT0 to NT3 NT0 being the youngest terrace and NT-3 the oldest terrace. These terraces are separated by the scarp both curvilinear and linear in nature facing towards river side. These are abandoned flood plains represent the level of former valley floor in the area, and were formed by 
cumulative climato-tectonic changes in the watershed of Narmada in the Quaternary times.In Narmada NT0 and NT1 area depositional terraces whereas NT2 \& NT3 are erosional terraces. These are both depositional and erosional terraces which are cyclic and non cyclic in nature and paired equvalent on both side of river. The Narmada exhibits swelling and pinching nature along its course of $1300 \mathrm{kms}$, between AmarkantakamdBharouch the channel course of Narmada is mainly controlled by ENE-WSW lineament and its sympathetic fractures. The Narmada in Jabalpur _ Harda and Gurdeshwar _ Bharouch section embodies prominent blanket of Quaternary deposits which display steepped sequence of river

terraces. These terraces are seprated by linear and curvilinear scarp facing river.In Jabalpur_Harda section Hiran Dudhi, Shakker, Sher and tawa are the prominent tributaries.

The Quaternary plain of Narmada display fluvial terraces of the stepped topographic benches, which from the prominent Quaternary landscape flanking Narmada Valley, indicate the former levels of flood-plain or valley floor. These land forms have been formed by combined action of erosion and depositional process of stream, the up warping in the hard ward ends and consequent climatic change in the post-Pleistocene time.

The Narmada basin is bounded by Narmada north and Narmada south faults, located in the apex zone of northward convexity in the Narmada south fault. At places (e.g. around Hoshangabad), the northern limit of the basin transcends Narmada north faults. The Quaternary lithic fill rests over Gondwana sediments, Mahakoshals, Deccan Trap, Granites and Bijawars.

The Narmada plain is studded with ENE-WSW elongated ridges bearing imprints of polyphase folding in the Sihora Sleemanabad area. Denudational ridge in the Deccan Traps of Barela-Mandla region, show imprints of dominant ENE fabric.

The area studied evolved in response to topography and landscape profile in tectonic zone and reactivated superimposition of drainage o pre existing topography, lithology and structure. The Narmada Son lineament zones represent an interaction of lithology, structure and climate, illustrating time dependent reactivation history West, (1962;) Choubey (1971). The central part of the earthquake affected area is characterized by units of recent fluvial origin - Narmada-alluvium, whereas the area towards north exhibits units of Vindhyan syneclise, with valley and montane topography comprising hogbacks and cuestas. Further north, the syneclise has wide plateau with prominent scrap overlooking the Indo-Gangetic plains. Towards south in the Satpura block geomorphic units of extrusive origin with different levels of plateau, units of structural origin on the Mesozoic sediments and units of denudational origin culminate into high hill ranges with steep slope

In the northern flank of Narmada on southern margin of Vindhyans, dominant geomorphic forms are hogbacks and cuestas, while towards north, plateau, mesa and butte are prominent gromorphic feature. This geomorphic pattern indicates post Vindhyan and pre-Gondwana reactivation of NNF (North Narmada Fault). Con-spicuous leveldifferences in the Gondwana-Deccan Trap contact surfaces reflect the nature of the main ENE fault and cross fault in the Satpura ranges. Elongated plateau, mesa and butte in Deccan Traps of Seoni-Mandla-Balaghat-Jabalpur district the dominant structural control over the evolution of landforms. Southwestern regional gradient of laterite capping in the Amarkantak region indicates adjustment of plantation surfaces during Tertiary period (Roy Chowdhury el al., 1964).

A chain of detached/isolated slices of Mahakoshal volcano-sedimentary rocks are noted on southern fault bound margin. Tiwari and Bhai, (1997),The detailed sedimenta -logical analysis of quaternary sediments of surface, both paleo and present domain of Narmada, bore hole sediments form surface up to the depth of $350 \mathrm{~m}$ below the surface, analysis of paleo-sole horizon ,quartz grain morphology of both e quaternary sediments and tephra soil and tephra stratigraphy, lithological assemblage, biostratigraphy and magnetostratigraphy have identified seven lithostratigraphic units o the surface of fluvial domain of Narmada, where the boulder bed represent the glacial phase at the base of Narmda trench boulder conglomerate glacial- fluvio and River terraces fluvial phase in increasing antiquity. The sediments of boulder bed and boulder comglomerate are concealed under younger deposits, are not fully exposed in the valley, however the detailed sedimentological ,haevy minerals, quartz grain morphology and paleo soles Khan et.al (1991). Khan et .al (2012) Khan et .al (2012) Khan et .al (2013) Khan (2014), Khan (2014), Khan et.al (2016), Khan et.al (2015) Khan et.al (2016), Khan et.al (2016), Khan et.al ( 2016), Khan et.al (2016) Khan et.al (in press ), khan et.al (in press ) has established a record of Quaternary deposits from Lower Pleistocene to Holocene. 
The Narmada valley in eastern and central segment exhibits a combination a mixed topography and quaternary plain with inselbergs, highlands and trappean plateau. The area in north and south of Jabalpur-Narsighpur-Hosangabad are occupied by plateau. The central part is a valley gape occupied by Quaternary sediments which have been accumulated in liear trench. This alluvial plain is drained by Narmada, Gaur, Hiran, Sher, Shakker, Dudhi, Tawa and Ganjal rivers and their tributaries. On the basis of altitudinal variation, five prominent geomorphic surfaces between $310 \mathrm{~m}$ and $585 \mathrm{~m}$ above MSL have been identified. The average elevation in the plain is around 390m MSL with the gradient from east to west. The plain is dooted with low inselbergs and mesas. The plateau in the southern sector attains an elevation of 585m MSL near Bamhni and in the northern area, the elevation is around 501m MSL near Bichhua village. In the eastern sector, Barela and Sihora area attain an elevation of $526 \mathrm{~m}$ and 508m MSL, respectively. The southern plateau has a general ENE-WSW trend, while the northern plateau extends E-W. The highland and plateau show evidences of several cycles of erosion during the geological time. The plain of Gaur, Hiran and Narmada are accretional in nature.

A chain of detached/isolated slices of Mahakoshal volcano-sedimentary rocks are noted on southern fault bound margin. Tiwari and Bhai, (1997), The detailed sedimentalogical analysis of quaternary sediments of surface, both paleo and present domain of Narmada, bore hole sediments form surface to $350 \mathrm{~m}$ below the surface, analysis of paleo-sole horizon ,quartz grain morphology of both e quaternary sediments and tephra soil and tephra stratigraphy, lithological assemblage, biostratigraphy and magnetostratigraphy have identified seven lithostratigraphic units of the surface of fluvial domain of Narmada, where the boulder bed represent the glacial phase at the base of Narmda trench boulder conglomerate glacial- fluvio and River terraces fluvial phase in increasing antiquity. The sediments of boulder bed and boulder comglomerate are concealed and not fully exposed in the valley a punctuated record of Quaternary from Lower Pleistocene to Holocene has been established (Khan et.al 1991). (Plate No 1, 2,3,4,5)

\section{Quaternary Sedimentation:-}

The Narmada Rift System consists of symmetrical basins that have been evolved in different stages of tectonisam. The $100-120 \mathrm{~km}$-wide ad $1300 \mathrm{~km}$ long rift bounded by Satpura in south and Vindhyan in north constitutes conspicuous ENE-WSW to E-W rift basin zone is filled with Pliocene-Pleistocene sediments, whereas some of them contain Miocene sedimentary deposits. Most of the sedimentary sequences contain faunal and floral remains including hominid species.

The Narmada Rift valley formed a linear trench in the middle of Indian subcontinent was an ideal locus for accumulation of sediments. The rift trench is intruded by the dolerite and other mafic and siliceous dykes and sills along lineaments in different phases of tectonic deformation. The Quaternary sedimentation incepting from glacial activity, followed by fluvio-glacial, lacustrine and fluvial phase within the rinsing and sinking environment, block faulting and segmental and linear displacement and dislocation, uplifting and isolated domal up- lift, Neogene rifting and Quaternary sedimentation and rift-bound Pliocene-Pleistocene rifting and volcanic activity specifically during glacial and fluvio-glacial phase are major component of the Quaternary period and tectonic processes of the Narmada Rift System and form the base of quaternary deposits. The Quaternary sedimentation was triggered by tectonic activities / up lift and climatic changes. The provenance for these sediments is the weathering products of eroding pre- Cambrian, meta-sediments, sedimentary and volcanic rocks along the watershed upland, rift escarpments and shoulders; faulted and uplifted blocks, volcanic fissure zones, and plateaus within and outside the rift. The Narmada Rift System, bounded by adjacent plateaus rising 300-700 m above the rift floor, consists of number symmetrical and symmetrical faulted blocks, escarpment, rock cut terraces, rock floors and segments of micro half grabben. Although rift-related basins started to form during the late Oligocene to early Miocene times, the Narmada Rifts were fully defined by middle to late Miocene time.

The Miocene -Pliocene-Pleistocene lake deposit of Katni on the eastern rift shoulder was created by faulting, topographic control, or isostatic depression similar to that of other Rift system.

The sequence of quaternary dposits depicts cyclic environmental transitions of the rift basins are caused by tectonic activities (uplift and subsidence), changes in relief, and climatic variations. The climatic changes in uplift, topographic and landscape features, coupled with block faulting, rinsing and sinking platform, created basins for the accumulations of thick lacustrine and fluvial sediments sequences with terrestrial and aquatic fossils. The sequential change in the sediment fancies from finely bedded lacustrine deposits to fluvial sediments are commonly noted in 
the sedimentary sequences and reflect environmental and tectonic changes that can be temporally determined. Moreover, regional correlation based on the chemistry and geochronology of interbedded tephra has made it possible to establish accurate stratigraphic relations that are useful for pale- environment reconstruction and evolutionary studies of fossil remains in the Narmada rift valley Khan et.al. ( 2012). The regional tephra correlation is being used increasingly to link sites together, and has already established that similar tephra layers are known from other parts of rift valley, as well as from other basin and peninsular India Achariya,( 1993 ), Khan (1992) Khan et.al. (2012) Tiwari (1996).

Moreover, because of tephra layers in sedimentary basins of different geologic periods, processes such as faulting, rifting, sedimentation and digenesis, impact of climatic changes, age of fossils, nature and acquisition of archeological implements, and the origin, distribution, and functional significance of early hominid artifact assemblages can be deciphered. However, evidence of the effects of tectonics on fauna and flora are distinct and their signatures on concealed fossiliferous horizons are uncontrolled and ill defined in the ecosystem in the valley during the Pliocene-Pleistocene periods. The boulder conglomerate which yielded the skull cap of Homo eructs in Narmada rift from Hathnora Sonakia (1984) remainedonly discovery of hominid fossil in last two and half decade due inconsistency concealed nature of fossiliferous horizon due faulting, and subsidence of Quaternary blanket of Narmada rift system as such researcher and scientist failed to add any further knowledge to hominid discovery any further.

In the Narmada valley the River terraces (NT-1 NT-3) represent sediments of Sohagpuur, Shahganj and Hoshangabad formations, and date back to the Late Pleistocene. The sedimentation commenced with a break in sedimentation after deposition of sediments of boulder form the base of rock basin. The break is represented by boulder conglomerate which is the persistent horizon and represents a specific phase of sedimentation in the rift valley. The sediments of paleo fluvial domain of Narmada were deposited in to two phases of sedimentation with a sharp break marked by tectonic and related climatic changes. The sediment of first phase of paleo domain of Narmada represented by Sohagpur formation overlies the boulder conglomerate followed by the fluvial flood plain deposit of Shahganj formation. The sequence of these to formation is exposed in the cliff section which represents different sediment facies typical of fluvial environments. The sequence of sediments display imprints of compressive tectonic regimes of sedimentation. The southern margin of lower Narmada is marked by Narmada-Son Fault the transformation of this geofracture. The other evidences evidence for prevalence of compressive stress regime in the central sector of Narmada basin is provided by numerous reverse faults in the Neogene sediments exposed immediately to the south of Narmada-Son Fault (Agarwal, 1986). These evidences suggest that the sediments of both the formation were formed in a compressive tectonic environment. There are evidences of subsidence of basin which has been documented on landscape of basin which are authenticated by other studies exist from adjacent area of synsedimentary subsidence on alluvial plain sedimentation. The entrenched meander and cut off meander on the southern bank around Tamcharand Balkar South of Hathnora, channel braiding in Narmada and Tawa in south west of Hathnora is due tosudden loss of bed slope arepositive evidences of subsidence of southern block. It may also be inferred a low sinuosity in Narmada channel and sudden entrenchment between Dehri and Shahganj of about $12 \mathrm{~m}$ furthe revealed that area is under slow subsidence unstable and relatively fixed river system in a slowly subsiding basin for the deposition of these sedimentsin a thrusting environment along the NSF which is consistent with the subsurface studies.The disposition of terraces, entrenched meander, entrenched scar, configuration of stream net work highly braided nature of Tawa river suggest that area is under compressive stress along the NSF. The dispositiondivergence and convergence of drainage net in conformity of quaternary landscape is anomalous, further imprints and neosiesmic signatures on landscape profile reveled persistent instability of basin during sedimentation.

The tectonic uplift of the Narmada valley during the Early and Late Holocene suggests inversion of an earlier subsiding basin. Such inversions of the basin have been common in the Tertiary times and are well recorded in the sediments of that age (Roy, 1990). A symmetric convergence of the NT-1,NT-2 terraces, diagonal disposition of paired equivalent of terraces across the channel, divergent and linear disposition of cliff of NT-3 terrace in conformity of NSF constant subsidence of basin and in response to frequential movement and geotectonic activity along the NSF.In Narmada river section dislocation in the litho units deformation in muddy layer bulding in clayey strata and sediments across NSF, NNW tilting of the NT-1, NT-2 sediments litho units consisting of the Late Pleistocene sequence, the anomalous topographic slope in the same direction and the incised cliffs up to $12-16 \mathrm{~m}$ in the streams in the area, indicate pulsational unsynchronized neoseismic movements of Narmada graben along the NSF during the Early Holocene. 
The 5-8-m incised cliffs of the streams also suggest that this block escaped the uplift induced large scale incision going on simultaneously in other areas of the Narmada valley. The occurrence of ravines and association of deep gullies north of Hatnora is morph tectonic manifestation caused by the sudden vertical movement and block adjustment due subsidence resulting to sudden collapse of sedimentation platform.

In the Lower Narmada valley the Mid-Late Holocene Quaternary valley deposits is the product of a Holocene high sea-level-induced deposition in a deeply incised valley trench trough highly influenced by NSF. The Mid-Late which resulted in both estuarine ad fluvial sedimentation in the lower reaches. A significant slowing down of tectonic uplift facilitated the encroachment of the sea into the valley and the creation of a depositional wedge, which extended up to the deep in land foothills. The 5-10-m exposed thickness of the valley-fill sediments reveals tide dominated estuarine deposition in the lower reaches and fluvial deposition upstream of the tide reach.

In the middlle Narmada valley pre-existing quaternary platform of NT2 \&NT-3 of middle Pleistocene prior to induced sedimentation of tidal transgression was strongly induced by tectonic impulses of NSF. The relative disposition of Narmada and resulting terraces NT-2 NT-3, cliff alluvial bluff and scarp, reveals, the reactivation of Narmada due to sudden uplift and of the area and related eustatic changes in the sea level. The relative disposition of terraces, paring of terraces, imprinys of neotectonisam relict and hanging drainage, isolated occurnces of alluvial fan on the southern bank associated digonestic geomorphic elements and over all morphogenetic expression of narmada Rift valley in the area of study indicate that area is under stress and evolued under tectonically compressiveduring the Mid-Late Holocene.

The incursion and transgression of tides, present estuarine reach contains several islands, which are coeval with the terrace surface above the present tidal range. Hence, they are the products of estuarine processes of the Mid-Late Holocene and not those of the present day. Funnel shaped morphology and increasing tidal energy landward are characteristics of tide-dominated estuaries (Wright et al., 1973). Existing data suggest that the Mid-Late Holocene sea level has remained at the same level up to the present with minor fluctuations. The Mid-Late Holocene sediments show tilting of $10-20 \mathrm{j}$ which is more pronounced in the vicinity of the NSF suggesting that the incision and uplift of the valley-fill terraces well above the present day tidal limits is related to the continued differential uplift along NSF.

The Narmada currently, the river occupies the northern margin of the Early Holocene channel belt and is clearly more sinuous. It exhibits a narrow channel with wide meanders inside wide belts of Mid-Late Holocene terraces.In the Narmada valley the River terraces (NT-3) has occupied large area on the both bank of Narmada. It extends from Sohagpur to Shivpur in the west on southern bank and on the north bank it is restricted in the north western corner in between Makalbard and Semrikhojre. The average elevation of this surface is about $75 \mathrm{~m}$ above m.s.l, separated by both linear and curvilinear scarp from NT-2. The average height of cliff is about $325 \mathrm{~m}$ above the m.s.l. The sediments comprised of this terrace are exposed in the cliff section. The oldest deposit of the exposed sediment successions a highly pedogenised mottled clay horizon showing vertisolic characters like extensive fracturing giving rise to blocky aggregates, seudo anticlines and hydro plastic slickenside along the fracture surfaces. The basal unit consisting of rock pebbles with clays is overlain by thick fluvial sediments, which comprise alluvial plain facies. The fluvial sediments indicate deposition in single phase of fluvial sedimentation with a sharp break marked by tectonic changes and related climatic changes. The sequence of this formation is exposed in the cliff section, is marked by the major break in sedimtation as witnessed by the occurrence of persist ent pebble horizon at the base .This formation represent different sediment facies typical of fluvial environments. The sequence of sediments display imprints of compressive tectonic regimes on sedimentation.

\section{Quaternary Geology:- \\ Boulder Bed:- \\ (Glacial/Fluvial-glacial deposits)}

The glacial and fluvio-glacial deposits of Narmada unconformable overly the Vindhyan and the basaltic Deccan Trap rocks. The sediments consist of a Hetero-heterogeneous assemblage of sub-angular to angular, sub-rounded, unsorted, stratifiedrock fragments ranging from boulders to small pebbles, predominantly of quartzite, gneiss, sandstone, basalt, jasper, chart, gneiss, sandstone, basalt, chart, altered feldspar, ferruginous nodules, in a matrix of very coarse to very fine-sand, silt and clay. These clastics are highly angular, generally poorly sorted and isotropically imprecated. Fine sediments comprise of reddish grayish and greenish sand with appreciable amount of mica flaks, altered feldspar, brick-red and buff silt, greenish-brown silt and clay, and greenish, reddish and dark 
maroon hard and plastic clay. These fine sediments contain fairly good amount of ferruginous material, quartz, mica flakes and altered feldspar grain. Through these sediments are similar in composition to the other deposits of Narmada Valley, exhibit entirely different sedimentary pattern, sediment characters and mineral composition. These rock clastics are largely angular, very poorly sorted and demonstrate isotropic imbrications pattern in the valley. The sediments of glacial domain of Narmada occur between and average depth of about 320-265 below the surface and were deposited in glacial environments during Pleistocene time. These deposits are concealed under boulder conglomerate in the valley.

(Boulder Conglomerate)

(Fluvio-glacial deposits)

The Vindhyan Group of rocks and Deccan Trap in the Central sector of the Narmada Valley form the basement for the Quaternary deposits. The conglomerate bed that constituted the fossiliferous horizon of Narmada is sandwiched between older Alluvium and the glacio-fluvial bounder bed. This conglomerate bed is a very persistent marked horizon indicating a distance phase of sedimentation in the Narmada Valley. It is exposed in the bluff/scrap of Narmada around SardarNager, Hathnora, Surajgarh, Budhni, Hoshangabad, Khoksa, Tigharia, Demawar and Bhariya-Ghat at the base of terraces $\mathrm{NT}_{2}$ (Khan, 1984). The measured thickness of the exposed boulder conglomerate varies from 1.5 to $6.5 \mathrm{~m}$ but average $5 \mathrm{~m}$.

The boulder conglomerate predominantly consists of sub-rounded to well-rounded boulder, cobble and pebble of quartzite, gneiss, sandstone, basalt, agate, jasper, chert, chalcedony tightly cemented in a matrix of sand and silt. The finer sediments include different grade of sand and silt, brown and maroon in color often laminated and cross laminated. The boulder conglomerate has yielded fossil skull cap of early man Homo erectus (Sonakia, 1984)

The boulder conglomerate consists of three sub-litho units; each sub-unit characterized by distinct rock fragment shape, size, lithological abundance and allied sediment characters. The sub-units are composed of variable assemblage of quartzite, gneiss, basalt, sandstone, agate, jasper, chalcedony, chart, sand and silt (Khan1992) These sub-litho units display fancies variation in the valley and upper units grades into gritty sandstone upstream of Hathnora

These deposits identified between an average elevations of 245 to $300 \mathrm{~m}$ above m.s.l. the basal unit of boulder conglomerate identified is marked at an elevation of about $268 \mathrm{~m}$ above m.s.l, exposed on the northern bank of Narmada around Hathnora ( $22^{\circ} 52^{\prime \prime} \mathrm{N}-77^{\circ} 52^{\prime}$ E) skull cap of early man Homo erectus (Sonakia, 1984) is recovered from boulder conglomerate located at the depth of about $83 \mathrm{~m}$ in stratigraphic column of Quaternary sediments of Narmada.

The boulder conglomerate is of middle Pleistocene age equivalent to Siwalik boulder conglomerate (India), Trinil bed of Java (Indonesia) and boulder conglomerate of Tapti (Khan. These deposits have yielded skull cap of early man, Homo erectus Narmadensis along with other mammalian fossils (Sonakia, 1984). The Ash bed of Quaternary age is recorded associated with these deposits around Timrawan upstream of Hathnora is of aeolian nature and perhaps indicates volcanic activity during middle Pleistocene time.

\section{Flood plain deposit of paleo domain of Narmada:-}

(Fluvial deposit)

The sediments of paleo-domain of Narmada conformably overlie the boulder conglomerate and represent the floodplain fluvial facies of the Narmada. The sediments of the fancies predominantly consist of clay silt and sand, discontinuous nodules and plates. The beds are horizontal, exhibit upward fining sequence typical of fluviatile deposits .This domain may be divided into three formations based on lithology, sediment assemblage, shape and size of rock clastics, relative disposition and diagnostic sedimentary characteristics. These formations are, viz. (i) Shohagpur, (ii) Shahganj, and (iii) Hoshangabad Formations respectively. These formations represent the sediments the complete sequence of Narmada deposited in channel and flood plain environments during Upper Pleistocene times. The lowest Sohagpur Formation is named after Sohagpur town. The unit occurs along the outer flanks of Narmada Valley bounded by Vindhyachal range to the north and Satpura to the south. It consists of sediments of paleo-domain of Narmada. It is represented by a thick sequence of clay, silt-sand and rock gravels. The unit is divisible into three sub litho unit. The basal sub-unit is chiefly red and brownish sand, silt, clay containing appreciable amount of cal matrix. The average measured thickness of this sub-unit is about $6.25 \mathrm{~m}$. The middle subunit consists of yellow and brownish silt, clay with subordinate sand and occasional rock gravel lenses. The average 
measured thickness of this sub-unit is about $5.50 \mathrm{~m}$. The upper sub-units predominantly consist of compact yellow clay, silt and calcareous concretion. The average measured thickness of this sub-unit is about $3.25 \mathrm{~m}$.

The Sohagpur formation is often association with discontinues and persistent pebbly horizon containing well sorted polymodal gravel of quartzite, gneiss, basalt, agate, jasper and chart in the matrix of course to fine-sand. The gravel is general discoidal, spherical and exhibits higher indices of sphericity and roundness indicating their derivation from distance and mixed provenance during sedimentation.

The Shahganj formation is forms litho-stratigraphic unit overlying boulder conglomerate and occupies large area in the central part of the valley. It is exposed in the bluff section of Narmada around Narayanpur, Sardarnagar, Hathnora, Shahganj and Hoshangabad. This formation is equivalent to the Shivpur formation described by Khan (1984) from the down stream of Hoshangabad. It consists of sediments of palaeo-domain of Narmada. It is represented by clay, silt, sand accompanied by inconsistent pebbliferous bed containing quartzite, gneiss, basalt, chart, agate. The average measured thickness of this formation is about $15 \mathrm{~m}$. These sediments constitution three units each characterized by distinct lithology, rock classics and diagnostic sediment characters.

The Hoshangabad is the younger formation of the Narmada and is represented by the flood plain fancies. It forms a distinct morphostratigraphy unit; above the present day flood plain of Narmada. It is crescent-shaped and is confined within the meander looped of the Narmada. This formation comprises three units. The basal unit predominantly consists of rock gravels of quartzite, gneiss, basalt and agate imbricated in the grayish sand and silt. The middle unit is represented by unconsolidated imbricated matrix of sand and silt supported by bimodal sorted gravel of quartzite, basalt, agate and chart. The upper unit contains yellowish and brownish silt and clay with occasional calcium concretion. It is capped by black soil. The measured thickness of the units is $6.5 \mathrm{~m}, 5.00 \mathrm{~m}$ and $3.5 \mathrm{~m}$ respectively. The sediments of fluvial domain of Narmada identified between elevations of 268 to $350 \mathrm{~m}$ above m.s.l. and were deposited in channel and flood plain environments during upper Pleistocene time. The sequence of Quaternary events and the history of sedimentation of Narmada indicate that the upper $70 \mathrm{~m}$ top $90 \mathrm{~m}$ of the Narmada alluvium was deposited in a single aggradations episode with minor pauses when dissection of the alluvium produced two terraces $\left(\mathrm{NT}_{3}-\mathrm{NT}_{2}\right)$. The sediments of this aggradations episode constitute three lithostratigraphy units viz. Boulder conglomerate, Sohagpur and Shahganj formation. The sediments of the alluvial phase are underlain by a boulder bed of glaciao-fluvial origin. Thus, the fossiliferous boulder conglomerate, the basal unit of alluvium marks a disconformity between the lower glacial-boulder layer and upper fluvial sediments. The fossiliferous basal boulder conglomerate is being of middle Pleistocene age (Khan 1992)

The sediments of present domain of Narmada is represented by sediments of active flood plain, point bar and sand bar facies of present domain and consist of unconsolidated imbricated, stratified, polygonal sorted rock-gravel supported by very coarse to very fine-sand and is named as Janwasa formation, after the village Janwasa where is it best developed. The measured thickness in the valley is about 5m. (Plate No _1, 2, 3, \&5)

\section{Geomorphology:-}

The Narmada in Central sector along its tributaries has chiseled a trigger shaped basin between the Vindhyachal range in north and the Satpura in the south. The gape between these two physiographic highs is filled by thick pile of Quaternary sediments which constitute complete quaternary sequence of Narmada and represents the oldest Quaternary deposit of peninsular India.

The Quaternary blanket forms conspicuous landscape of river terraces in central segment of valley between representing the former level of valley floor of Narmada controlled by ENE -WSW to E-W lineament. The Narmada has formed three regional terraces besides its flood plain (NT). These are polycyclic depositional terraces and are designated as NT1, NT2 and NT3 in increasing order of antiquity from the present course of river. These terraces display convergence and divergences in their relative disposition have pairequivilent andare separated by linear or curvilinear scarp facing the river.

The NT1 is the youngest lowest terrace forming present flood plain of the Narmada and is marked by a scarp. It is restricted within the meandering loop of Narmada; is a depositional terrace and has convergent relation with older terraces and is of cyclic nature.The NT2 is a regional terrace occupying the central part of valley, separated by conspicuous scarps from NT3 and NT1. It is an erosional terrace and forms the main alluvial plains of the Narmada, is a cyclic terrace and has paired equivalents across the valley. It exhibits divergent relationship, with NT3 and 
present day course of Narmada along the outer flanks of the valley, resting either on the Vindhayan or Deccan basaltic rocks. The relative disposition of older terraces NT2 and NT3, their cyclic nature, and divergent relationship amongst each other and with the present course of river in the valley indicate high energy condition of Narmada during the formation of these terraces.s The non-cyclic nature of NT1 and its convergent relation with NT2 and NT3 and present day course of Narmada indicates climatic changes towards the later history of sedimentation. The over all disposition of these terraces in the valley, their relative convergent and divergent relation and their relation to the present day course of river, indicates constant decrease in the rate of uplift in watershed region and consequent decrease in energy condition of Narmada towards later Quaternary time.

Table No 1:- Morphostratigraphy of the Narmada Alluvium.

\begin{tabular}{|c|c|c|}
\hline Terrace Elevationabove MSL & Nature of its Origin & Morphostatigraphy \\
\hline $\begin{array}{ll}\text { NTo } & 260-280 \mathrm{~m} \\
\end{array}$ & Depositional & Light grey to dark grey sand and silt \\
\hline $280-300-\mathrm{m}$ & $\begin{array}{l}\text { Erosional / } \\
\text { Depositional }\end{array}$ & $\begin{array}{l}\text { Light grey to dark grey sand and silt } \\
\text { with rock pebble sand and silt }\end{array}$ \\
\hline $\begin{array}{ll}\mathrm{NT}_{-2} \mathrm{~A} & 300-320 \mathrm{~m} \\
\end{array}$ & Depositional & Grey \& brown sand and silt. \\
\hline $\mathrm{NT}_{2} \mathrm{~B} \quad 320-340 \mathrm{~m}$ & Depositional & Yellow brownish clay with silt \\
\hline NT_2C $\quad 340-360 \mathrm{~m}$ & $\begin{array}{l}\text { Erosional / } \\
\text { Depositional }\end{array}$ & Yellow brownish clay with siltwith \\
\hline & $\begin{array}{l}\text { Dark brown oxidized } \\
\text { clay silt }\end{array}$ & \\
\hline $\mathrm{NT}_{-3} \mathrm{~A} \quad 360-380 \mathrm{~m}$ & Depositional & $\begin{array}{l}\text { Dark brown, dark yellow clay silt } \\
\text { Brownish red clay and silt with } \\
\text { Calc-matrix. }\end{array}$ \\
\hline $\mathrm{NT}_{-3 \mathrm{~B}}$ & $\begin{array}{l}\text { Erosional/ } \\
\text { Depositional }\end{array}$ & $\begin{array}{l}\text { Dark brown, dark yellow clay silt } \\
\text { Brownish red clay and silt with } \\
\text { Calc-matrix }\end{array}$ \\
\hline
\end{tabular}

Janwasa Surface :- (NT0)

It is the youngest surface of the Narmada in the area. It is noticed above the present day flood plain of Narmada at an average elevation of about $280 \mathrm{~m}$ above the m.s.l. This surface is characterized by lack of drainage, gentle slope and scanty vegetation. The geomorphic features associated with this surface are strand lines, meander scroll, and active flood plain. It is observed around Hoshangabad, Shahganj, Hathnora and Upstream of Sardarnagar.

\section{Hoshangabad:- (NT1)}

It is older than Narmada surface and named after Hoshangabad (22 $15-7743)$ town where it is best developed. The surface forms the morpho-stratigraphic unit and is identified at an average elevation of about $295 \mathrm{~m}$, above m.s.l. around Hoshangabad, Sahaganj, Hathnora, Narayanpur, Dheri and Ramnagar. It is crescent shaped and is characteristically restricted within the meander of Narmada exhibiting diagonally disposed paired equivalents in the valley. It represents the sediments of palaeo-domain of Narmada predominantly consisting of sand, silt and rock gravel. The top soil mostly comprised of light yellow and grey clay silt of about $1.20 \mathrm{~m}$. The depth of weathering varies from 0.35 to $1.50 \mathrm{~m}$. and average depth is $1.15 \mathrm{~m}$. The streams which drain this surface are mostly impersistent and partly of internal nature. These streams are generally sub-parallel to parallel and sub-dendritic in nature and appear to have been controlled by concealed fracture planes. The various erosional pattern identified in this surface are rill erosion and gulley erosion.

\section{The Sahaganj surface (NT2):-}

It is older than Hoshangabad surface, is identified at an average elevation of $310 \mathrm{~m}$. above m.s.l. named after Sahaganj (22 51-77 47) the prominent village situated on this surface. It is a vast Quaternary surface and forms the central Narmada plain. It is separated from Hoshangabad surface (NT1) by conspicuous scarp along Narmada exposing thick sequence of Quaternary sediments in the bluff section. The bluff scarp of Narmada which persistently extends from Jabalpur to Harda along Narmada indicates sharp incision of valley floor by river which appears to be related with the reactivation of E-W trending lineament suggesting significant tectonic event in the Narmada valley in Quaternary time Khan et.al (2016).The heights of sharp edge scarp vary from 11 to $20 \mathrm{~m}$., the average height is about $16 \mathrm{~m}$. which increases upstream. 
The Sahahganj surface is separated from Sohagpur surface by a curvilinear scarp rising to the average height of about $18 \mathrm{~m}$. Though the scarp is quite prominent and forms the stepped sequence of terraces in the valley, at places it is distorted by erosional processes, creep and mass wasting activities along the scarp faces. The development of linear convex slopes along the scarp due to accumulation of mass wasting debris is the prominent feature.

This surface is deeply incised by network of small gullies and has developed small linear tracts of ravines north of Narayanpur, north east of Sardarnagar on the northern bank, around Dhansi and north of Balgaon on the southern bank of Naramada. It displays typical undulating bad land topography with micro scarps of average height of 3.25 $\mathrm{m}$. The prominent topographic breaks and undulations on this surface are noticed along subsequent and insequent stream rising from Vindhyachal in north and Satpura in south and draining in the valley. The extensive land dissection and intensive gullying on this surface is noticed along Narmada in Narayanpur, Hoshangabad, section around Sardarnagar, Hathnora, Sukkawara, east and south east of Sahahganj.

This surface forms the conspicuous landscape (NT2) of Narmada and represents the former level of valley floor. It consists of sediments of palaeo-domains of Narmada predominantly comprising of yellow, grey and reddish brown silt, clay sand and rock gravel. These sediments are capped by black cotton soil. The soil thickness varies from 1.35 $\mathrm{m}$ to $2.90 \mathrm{~m}$. and average thickness is about $2.25 \mathrm{~m}$. The weathered zone mostly follows the profile and an average depth of this zone is about $2.80 \mathrm{~m}$. This surface is drained by sup-parallel to parallel streams which appears to have been controlled by concealed fractures and lineaments. The prominent streams draining this surface are Chandani Nadi, Dobi Nadi, Katkasari Nadi, Nanawara Nadi and Palkamti Nadi. The various erosional patterns in this surface are soil erosion, deep gully erosion and accelerated headward erosion.

The geomorphic features associated with this surface is a cut off meander identified around Tamcharu (22 47 30-77 53 10) on the southern bank of Narmada. The linear length of cut off meander is about 11 kilometers, width varies from $250 \mathrm{~m}$ to $750 \mathrm{~m}$ and average width is $575 \mathrm{~m}$. It is marked by a scarp which rises to the height of about $10 \mathrm{~m}$. The slope is 2-5 towards north. It represents the paleo-course of Narmada and is locally known as "Budhi Narmada". The relative disposition of this cut off meander, slope elements and its relation to present course of Narmada indicates subsidence of southern block of Narmada and consequential sudden shift of Narmada towards north due to tectonic dislocation and reactivation in the energy system of channel under compressive environment in recent past.

\section{Sohagpur Surface (NT3):-}

It is oldest Quaternary surface (NT3) of the Narmada identified at an elevation of about $325 \mathrm{~m}$. above m.s.l. and named after Sohagpur (22 15 - 77 59) the main town situated on this surface. It occupies large area in the south and south eastern corner of the area. It extends from Sohagpur in the east to the Rajpura in the west on the south bank and from Makalbara in the east to Kewalajhir in the west on northern bank of Narmada. It occurs at about $40 \mathrm{~m}$. above the present day channel of Narmada and has gentle slope towards the west.

It represents the sediments of flood plain facies of paleo-domains of Narmada consisting of yellow red and brownish silt, clay containing fairly good amount of calcareous concretion and ferruginous matrix. It is capped by black cotton soil measuring about $3.25 \mathrm{~m}$. The depth of weathering follows the soil profile with an average depth of about $3.50 \mathrm{~m}$. It is drained by Rain Nadi, Tangas Nadi and Palakmati Nadi which are sub-parallel to parallel and are influenced by concealed fracture and lineament. The various erosion pattern noted on this surface are rill erosion, gully erosion and headword erosion.(Plate No 1,2 4,\&5). The diagnostic features and elements of terraces are incorporated in the Table No 1 to 7

Salient features of fluvial terraces in type area of jabalpur in nrmada valley:-

\begin{tabular}{|l|l|l|l|l|l|l|l|l|l|}
\hline TABLE NO_2 & \multicolumn{2}{|l|}{$\begin{array}{l}\text { GEOMORPHOLOGY AND DIGONESTIC ELEMENTS } \\
\text { NRMADA VALLEY }\end{array}$} & $\begin{array}{l}\text { Peniplain } \\
\text { Pediplain }\end{array}$ & Pediplain \\
\hline $\begin{array}{l}\text { Locality } \\
\text { SOHAGPUR }\end{array}$ & $\begin{array}{l}\text { Rive } \\
\text { r } \\
\text { bad }\end{array}$ & NTo NT1 & NT2-A & NT2-B & $\begin{array}{l}\text { NT2- } \\
\text { C }\end{array}$ & $\begin{array}{l}\text { NT3-B } \\
\text { NT3-C }\end{array}$ & PP & PD \\
\hline Age - & & & & & \multicolumn{3}{|c|}{ HOLOCENE--- } \\
\hline $\begin{array}{l}\text { Elavation above } \\
\text { MSL (m) }\end{array}$ & $\mathbf{3 0 0}$ & $\mathbf{3 1 0}$ & $\mathbf{3 2 0}$ & $\mathbf{3 2 8}$ & $\mathbf{3 4 0}$ & $\mathbf{3 4 5}$ & $\mathbf{3 5 5}$ & $\mathbf{3 5 8}$ & $\mathbf{3 6 2}$ \\
\hline Geomorphic & $\mathbf{0 . 0 0}$ & $\mathbf{1 0 . 0}$ & $\mathbf{1 0 . 0 0}$ & $\mathbf{8 . 0 0}$ & $\mathbf{1 2 . 0 0}$ & $\mathbf{5 . 0 0}$ & $\mathbf{1 0 . 0 0}$ & $\mathbf{1 3 . 0 0}$ & $\mathbf{1 7 . 0 0}$ \\
\hline
\end{tabular}




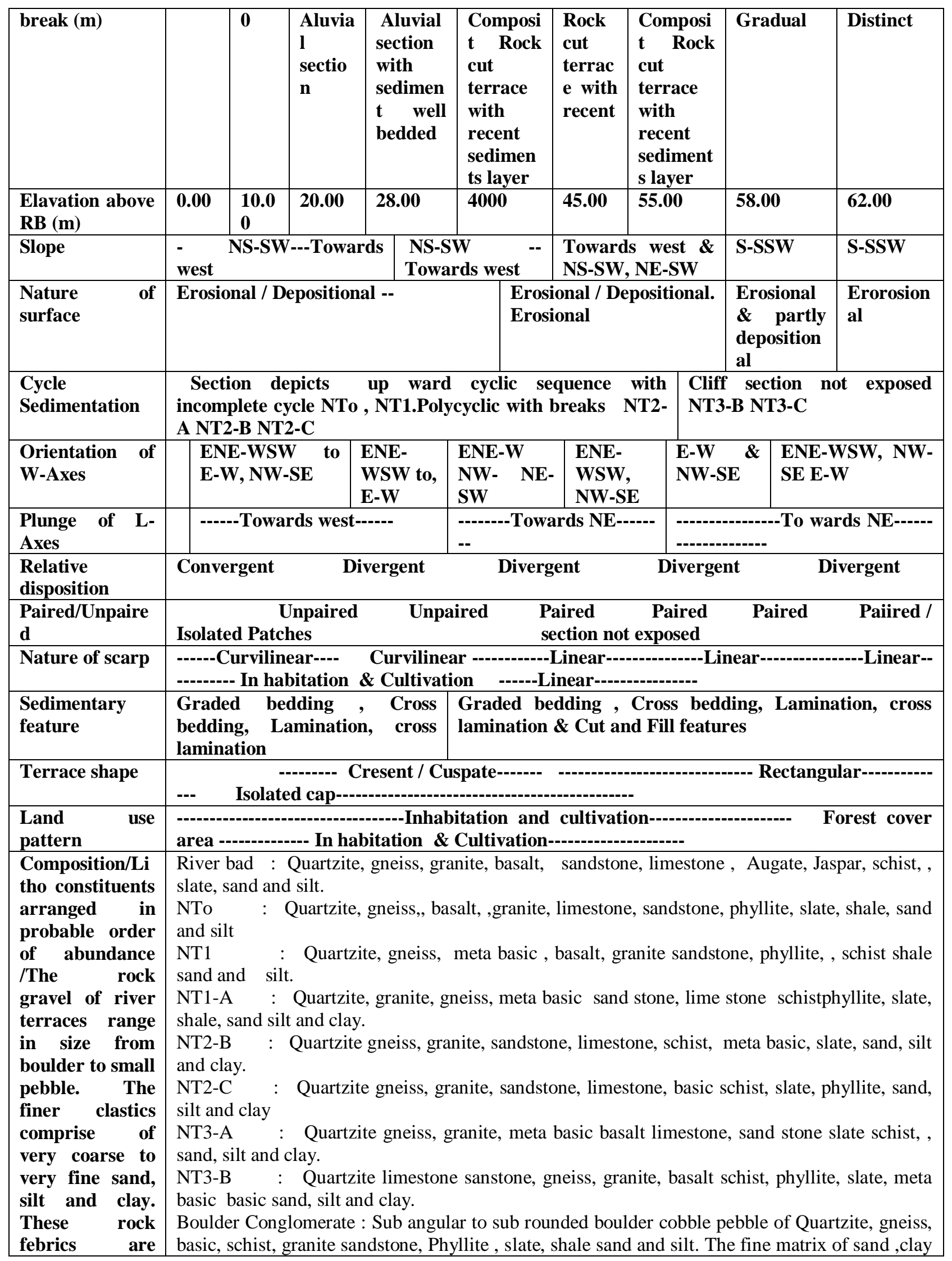




\begin{tabular}{|l|l|}
\hline generally & and silt is cross bedded, laminated with cut and features \\
surrounded to & Boulder Bed: sub angular to angular, sub round hybrid and heterogeneous assorted rock febric \\
well rounded & of Quartzite limestone, gneiss, granite, schist, , slate, sand, silt and clay. \\
and mostly & \\
spherical, \\
oblate, prolate \\
and bladed in \\
shape.
\end{tabular}

Salient features of fluvial terraces in type area of jabalpur in nrmada valley:-

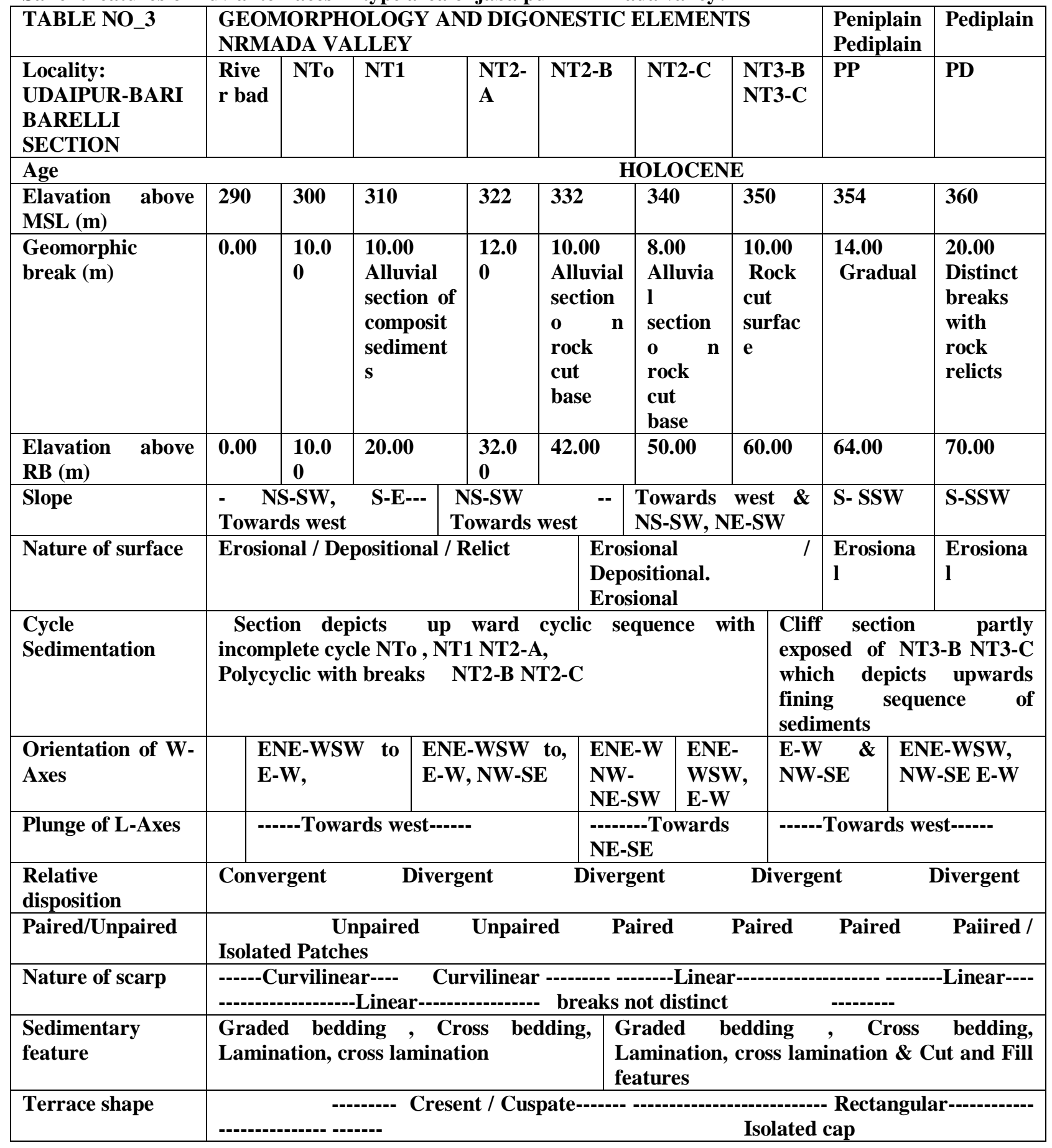




\begin{tabular}{|c|c|}
\hline Land use pattern & area- \\
\hline $\begin{array}{l}\text { Composition/Lith } \\
\text { o constituents } \\
\text { arranged in } \\
\text { probable order of } \\
\text { abundance /The } \\
\text { rock gravel of } \\
\text { river terraces } \\
\text { range in size from } \\
\text { boulder to small } \\
\text { pebble. The finer } \\
\text { clastics comprise } \\
\text { of very coarse to } \\
\text { very fine sand, silt } \\
\text { and clay. These } \\
\text { rock febrics are } \\
\text { generally } \\
\text { surrounded to } \\
\text { well rounded and } \\
\text { mostly spherical, } \\
\text { oblate, prolate } \\
\text { and bladed in } \\
\text { shape. }\end{array}$ & $\begin{array}{l}\text { River bad : Quartzite, gneiss, granite, basalt, meta basic, sandstone, limestone, Augate, } \\
\text { Jaspar, schist, , slate, sand and silt. } \\
\text { NTo : Quartzite, gneiss,, basalt, ,granite, limestone, sandstone, phyllite, slate, shale, } \\
\text { sand and silt } \\
\text { NT1 : Quartzite, gneiss, meta basic, basalt, granite sandstone, phyllite, , schist shale } \\
\text { Augate, sand and silt. } \\
\text { NT1-A : Quartzite, granite, gneiss, meta basic sand stone, lime stone schist,phyllite, } \\
\text { slate, shale, sand silt and clay. } \\
\text { NT2-B : Quartzite gneiss, granite, limestone, sandstone, schist, meta basic, slate, sand, } \\
\text { silt and clay. } \\
\text { NT2-C : Quartzite gneiss, granite, sandstone, limestone, basalt and meta basic schist, } \\
\text { slate, phyllite Jaspar, sand, silt and clay } \\
\text { NT3-A : Quartzite gneiss, granite, meta basic basalt limestone, sand stone slate schist, } \\
\text { sand, silt and clay. } \\
\text { NT3-B : Quartzite limestone sanstone, gneiss, granite, basalt schist, phyllite, } \\
\text { slate,sand,silt and clay. } \\
\text { Boulder Conglomerate : Sub angular to sub rounded boulder cobble pebble of Quartzite, } \\
\text { gneiss, basic, schist, granite sandstone, Phyllite, slate, shale sand and silt. The fine matrix of } \\
\text { sand ,clay and silt is cross bedded, laminated with cut and features } \\
\text { Boulder Bed: sub angular to angular, sub round hybrid and heterogeneous assorted rock } \\
\text { febric of Quartzite limestone, gneiss, granite, schist, , slate, sand, silt and clay. }\end{array}$ \\
\hline
\end{tabular}

Salient features of fluvial terraces in type area of jabalpur in nrmada valley valley:-

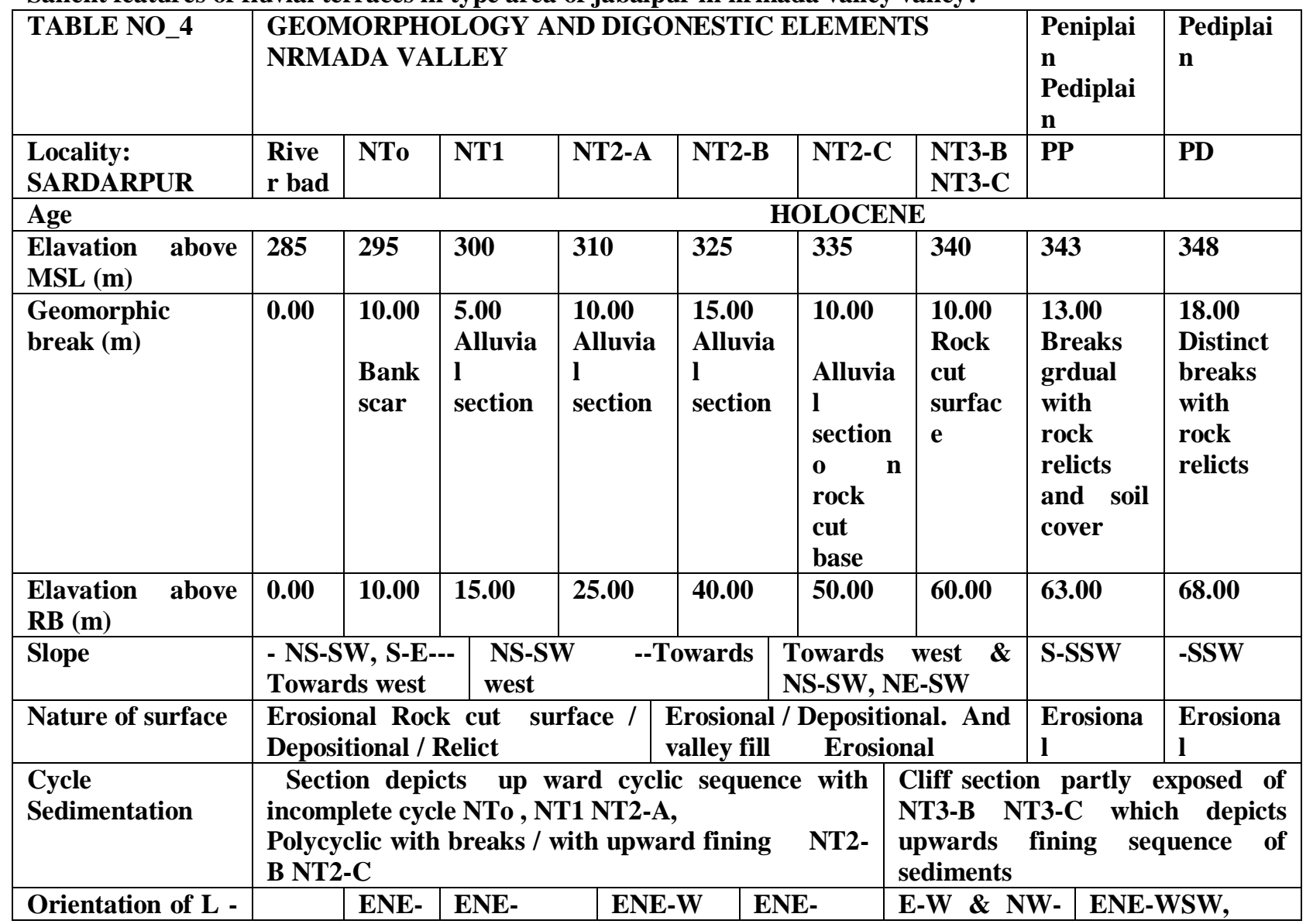




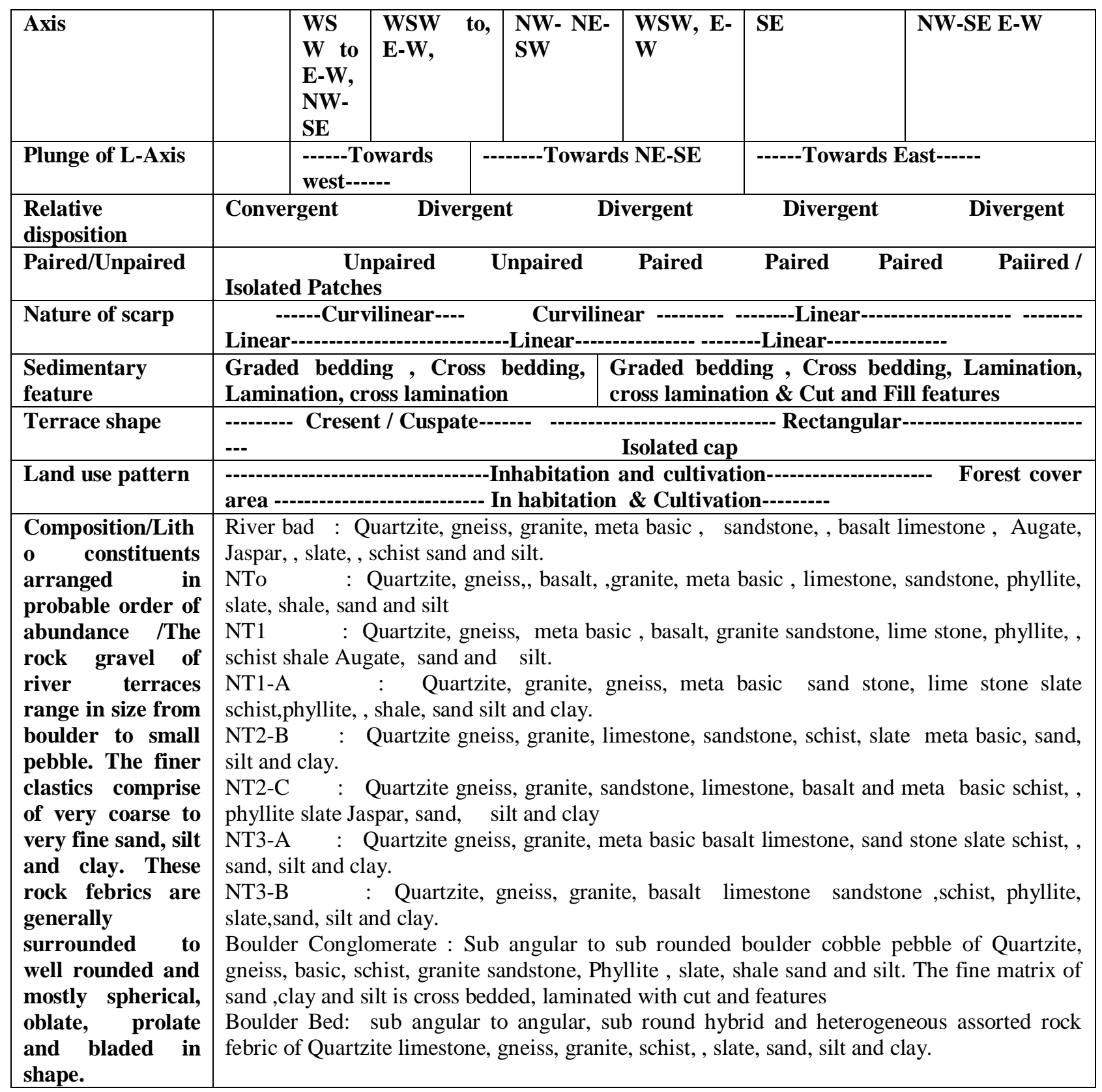

\begin{tabular}{|c|c|c|c|c|c|c|c|c|c|}
\hline \multirow{2}{*}{$\begin{array}{l}\text { Table no_5:- } \\
\text { Locality } \\
\text { :HATHNORA }\end{array}$} & \multicolumn{7}{|c|}{ geomorphology and digonestic elements nrmada valley. } & \multirow{2}{*}{$\begin{array}{l}\text { Peniplain } \\
\text { Pediplain } \\
\text { PP }\end{array}$} & \multirow{2}{*}{$\begin{array}{l}\text { Pediplain } \\
\text { PD }\end{array}$} \\
\hline & $\begin{array}{l}\text { River } \\
\text { bad }\end{array}$ & NTo & NT1 & $\begin{array}{l}\text { NT2- } \\
\text { A }\end{array}$ & $\begin{array}{l}\text { NT2- } \\
\text { B }\end{array}$ & NT2-C & $\begin{array}{l}\text { NT3-B } \\
\text { NT3-C }\end{array}$ & & \\
\hline Age & & \multicolumn{8}{|c|}{ HOLOCENE } \\
\hline $\begin{array}{l}\text { Elavation above } \\
\text { MSL (m) }\end{array}$ & 280 & 290 & 300 & 305 & 315 & 325 & 330 & 333 & 338 \\
\hline $\begin{array}{l}\text { Geomorphic break } \\
\text { (m) }\end{array}$ & $\mathbf{0 . 0 0}$ & 10.00 & 10.00 & 5.00 & 10.00 & 10.00 & 5.00 & 8.00 & 13.00 \\
\hline $\begin{array}{ll}\text { Elavation above } \\
\text { RB (m) }\end{array}$ & $\mathbf{0 . 0 0}$ & 10.00 & 20.00 & 25.00 & 35.00 & 45.00 & $\mathbf{5 0 . 0 0}$ & $\mathbf{5 5 . 0 0}$ & 60.00 \\
\hline Slope & \multicolumn{3}{|c|}{$\begin{array}{l}--- \text { Towards west } \\
\text { \& NS }\end{array}$} & ards we & \multicolumn{3}{|c|}{$\begin{array}{l}\text { Towards west \& NS- } \\
\text { SW, }\end{array}$} & S-SSW & S-SSW \\
\hline
\end{tabular}




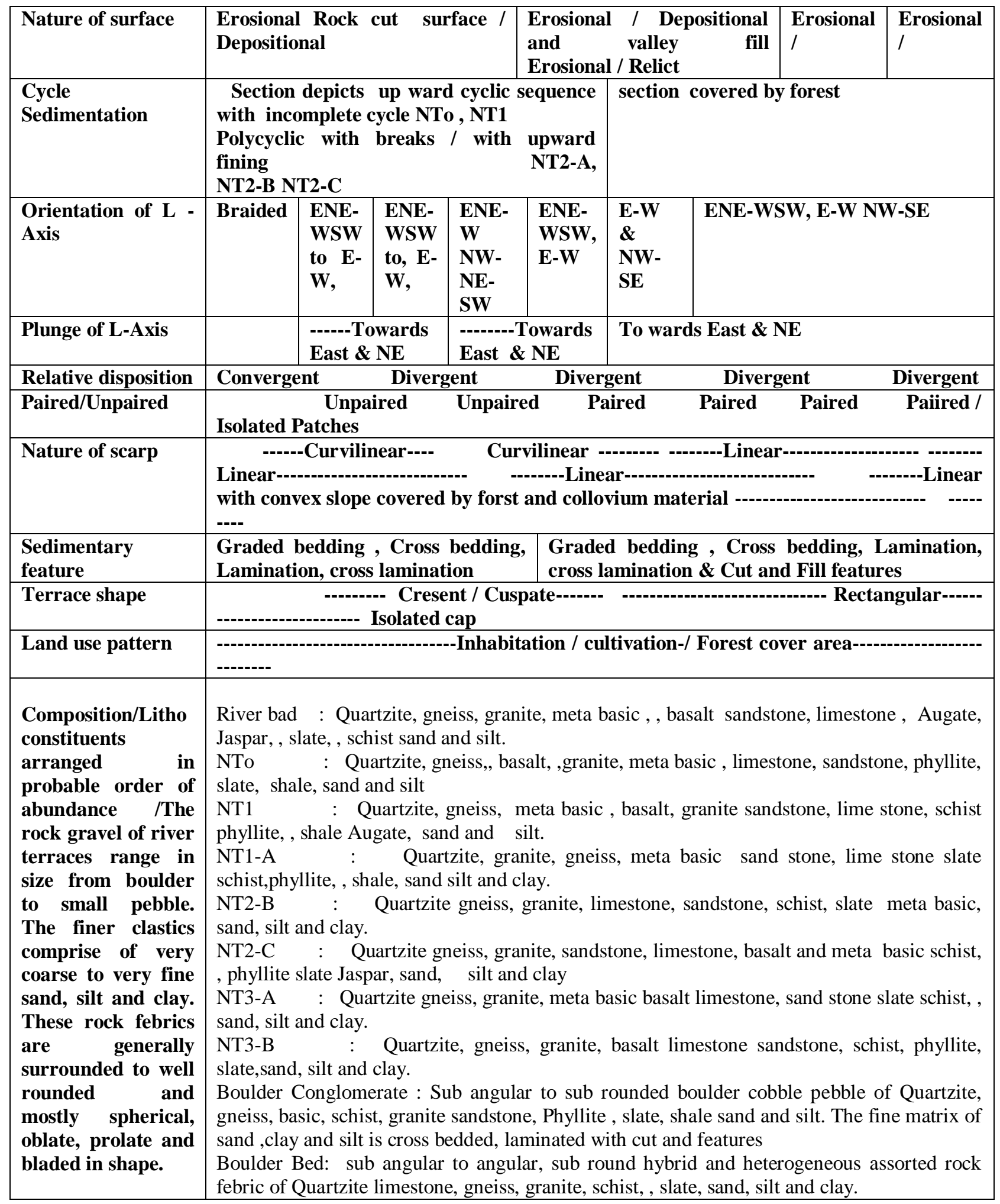


Salient features of fluvial terraces in type area of jabalpur in nrmada valley valley:-

\begin{tabular}{|c|c|c|c|c|c|c|c|c|c|}
\hline \multirow{2}{*}{$\begin{array}{l}\text { TABLE NO_6 } \\
\text { Locality : } \\
\text { HOSHANGABA } \\
\text { D }\end{array}$} & \multicolumn{7}{|c|}{$\begin{array}{l}\text { GEOMORPHOLOGY AND DIGONESTIC ELEMENTS } \\
\text { NRMADA VALLEY }\end{array}$} & \multirow{2}{*}{$\begin{array}{l}\text { Pediplai } \\
\text { n } \\
\text { PP }\end{array}$} & \multirow{2}{*}{$\begin{array}{l}\text { Pediplai } \\
\text { n } \\
\text { PD }\end{array}$} \\
\hline & $\begin{array}{l}\text { River } \\
\text { bad }\end{array}$ & NTo & NT1 & NT2-A & NT2-B & NT2-C & $\begin{array}{l}\text { NT3-B } \\
\text { NT3-C }\end{array}$ & & \\
\hline \multicolumn{10}{|c|}{ HOLOCENE } \\
\hline $\begin{array}{l}\text { Elavation above } \\
\text { MSL }(\mathbf{m})\end{array}$ & 260 & 270 & 280 & 285 & 295 & 310 & 315 & 318 & 322.00 \\
\hline $\begin{array}{l}\text { Geomorphic } \\
\text { break }(\mathbf{m})\end{array}$ & 0.00 & $\begin{array}{l}10.00 \\
\text { Alluvi } \\
\text { al } \\
\text { section }\end{array}$ & $\begin{array}{l}10.00 \\
\text { Alluvia } \\
\text { l } \\
\text { section }\end{array}$ & $\begin{array}{l}5.00 \\
\text { Alluvia } \\
\text { l } \\
\text { section }\end{array}$ & $\begin{array}{l}10.00 \\
\text { Alluvia } \\
\text { l } \\
\text { section } \\
\text { o n n } \\
\text { rock } \\
\text { cut } \\
\text { base }\end{array}$ & $\begin{array}{l}15.00 \\
\text { Alluvi } \\
\text { al } \\
\text { section } \\
\text { o n } \\
\text { rock } \\
\text { cut } \\
\text { base }\end{array}$ & $\begin{array}{l}5.00 \\
\text { Rock } \\
\text { cut } \\
\text { surface } \\
\text { with } \\
\text { thin } \\
\text { layer of } \\
\text { recent } \\
\text { sedimen } \\
\text { ts }\end{array}$ & $\begin{array}{l}5.00 \\
\text { Breaks } \\
\text { grdual } \\
\text { with } \\
\text { and soil } \\
\text { cover }\end{array}$ & $\begin{array}{l}4.00 \\
\text { Distinct } \\
\text { breaks } \\
\text { with } \\
\text { rock } \\
\text { relicts } \\
\text { and } \\
\text { imprints } \\
\text { of } \\
\text { erosiona } \\
\text { I } \\
\text { activity. }\end{array}$ \\
\hline $\begin{array}{l}\text { Elavation above } \\
\text { RB (m) }\end{array}$ & 0.00 & 10.00 & 20.00 & 25.00 & 35.00 & 50.00 & 55.00 & 58.00 & 59.00 \\
\hline Slope & \multicolumn{7}{|c|}{$\begin{array}{l}--- \text { Towards west } \\
\text { \& SW }\end{array}$} & & \\
\hline $\begin{array}{l}\text { Nature of } \\
\text { surface }\end{array}$ & \multicolumn{4}{|c|}{$\begin{array}{l}\text { Channel braiding } \\
\text { / Depositional }\end{array}$} & $\begin{array}{l}\text { Erosional } \\
\text { valley fill } \\
\text { Relict \& is } \\
\text { cut benche }\end{array}$ & $\begin{array}{l}\quad / \quad \mathrm{De} \\
\mathrm{F} \\
\text { solated ca } \\
\text { s }\end{array}$ & $\begin{array}{l}\text { positional. } \\
\text { aposional / } \\
\text { aps o rock }\end{array}$ & $\begin{array}{l}\text { Erosion } \\
\text { al / }\end{array}$ & $\begin{array}{l}\text { Erosion } \\
\text { al / }\end{array}$ \\
\hline $\begin{array}{l}\text { Cycle } \\
\text { Sedimentation }\end{array}$ & \multicolumn{5}{|c|}{$\begin{array}{l}\text { River bed with channel braids, poit bar, sand } \\
\text { bars, braided channel. NTo, NT1 section } \\
\text { depicts up ward cyclic sequence with } \\
\text { incomplete } \\
\text { NT2-B NT2-C display } \\
\text { Polycyclic with breaks / with upward fining }\end{array}$} & \multicolumn{4}{|c|}{$\begin{array}{l}\text { section not exposed and covered by } \\
\text { forest and colluvium /scree deposit }\end{array}$} \\
\hline $\begin{array}{l}\text { Orientation of } L \\
\text {-Axis }\end{array}$ & $\begin{array}{l}\text { Braide } \\
\text { d / } \\
\text { Grade } \\
\text { d }\end{array}$ & $\begin{array}{l}\text { ENE- } \\
\text { WSW } \\
\text { to E- } \\
\text { W, }\end{array}$ & $\begin{array}{l}\text { ENE- } \\
\text { WSW } \\
\text { to, E- } \\
\text { W, }\end{array}$ & \begin{tabular}{|l} 
ENE- \\
W \\
NW- to \\
N-E-
\end{tabular} & \begin{tabular}{|l|} 
ENE- \\
WSW, \\
E-W \\
NW- \\
SE
\end{tabular} & $\begin{array}{l}\text { E-W } \\
\& \\
\text { NW- } \\
\text { SE }\end{array}$ & ENE-WS & W, E-W & \\
\hline Plunge of L-Axis & & \multicolumn{2}{|c|}{$\begin{array}{l}---- \text { Towards } \\
\text { East----- }\end{array}$} & \multicolumn{2}{|c|}{ NE-SE \&E-W } & \multicolumn{4}{|c|}{ To wards Eeast and NE } \\
\hline $\begin{array}{l}\text { Relative } \\
\text { disposition }\end{array}$ & \multicolumn{2}{|c|}{ Convergent } & \multicolumn{2}{|c|}{ Divergent } & \multicolumn{2}{|l|}{ Divergent } & Divergent & \multicolumn{2}{|c|}{ Divergent } \\
\hline Paired/Unpaired & \multicolumn{3}{|c|}{$\begin{array}{l}\text { Unpaired } \\
\text { Isolated Patches }\end{array}$} & Unpaired & Pair & & Paired & Paired & Paiired / \\
\hline Nature of scarp & \multicolumn{9}{|c|}{ 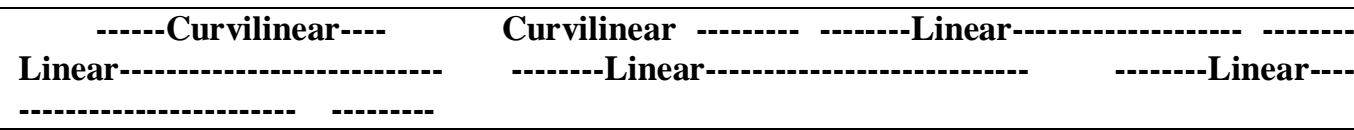 } \\
\hline $\begin{array}{l}\text { Sedimentary } \\
\text { feature }\end{array}$ & \multicolumn{4}{|c|}{$\begin{array}{l}\text { Graded bedding , Cross bedding, } \\
\text { Lamination, cross lamination }\end{array}$} & \multicolumn{5}{|c|}{$\begin{array}{l}\text { Graded bedding, Cross bedding, Lamination, } \\
\text { cross lamination \& Cut and Fill features }\end{array}$} \\
\hline Terrace shape & \multirow{2}{*}{\multicolumn{9}{|c|}{ 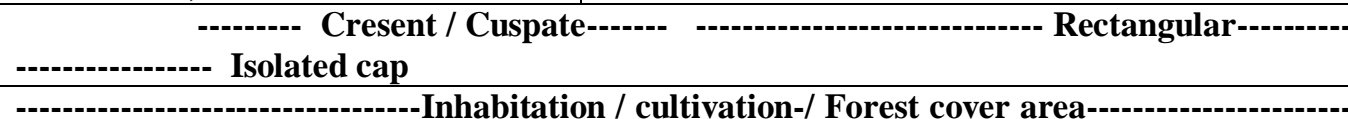 }} \\
\hline Land & & & & & & & & & \\
\hline
\end{tabular}




\begin{tabular}{|c|c|}
\hline pattern & \\
\hline $\begin{array}{l}\text { Composition/Lit } \\
\text { ho constituents } \\
\text { arranged in } \\
\text { probable order } \\
\text { of abundance } \\
\text { /The rock gravel } \\
\text { of river terraces } \\
\text { range in size } \\
\text { from boulder to } \\
\text { small pebble. } \\
\text { The finer } \\
\text { clastics comprise } \\
\text { of very coarse to } \\
\text { very fine sand, } \\
\text { silt and clay. } \\
\text { These rock } \\
\text { febrics are } \\
\text { generally } \\
\text { surrounded to } \\
\text { well rounded } \\
\text { and mostly } \\
\text { spherical, } \\
\text { oblate, prolate } \\
\text { and bladed in } \\
\text { shape. }\end{array}$ & $\begin{array}{l}\text { River bad : Quartzite, gneiss, granite, meta basic, , basalt , sandstone, limestone Augate, } \\
\text { Jaspar, slate, , schist sand and silt. } \\
\text { NTo : Quartzite, gneiss,, basalt, ,granite, meta basic, limestone, sandstone, phyllite, slate, } \\
\text { shale, sand and silt } \\
\text { NT1 : Quartzite, gneiss, meta basic, basalt, granite sandstone, lime stone, phyllite, schist } \\
\text { shale Augate, sand and silt. } \\
\text { NT1-A : Quartzite, granite, gneiss basalt, meta basic sand stone, lime stone slate } \\
\text { schist,phyllite, , shale, sand silt and clay. } \\
\text { NT2-B : Quartzite gneiss, granite, limestone, sandstone, schist, slate meta basic, sand, silt } \\
\text { and clay. : Quartzite gneiss, granite, sandstone, limestone, basalt and meta basic schist, , } \\
\text { NT2-C : } \\
\text { phyllite slate Jaspar, sand, silt and clay } \\
\text { NT3-A : Quartzite gneiss, granite, meta basic basalt limestone, sand stone slate schist, , } \\
\text { sand, silt and clay. } \\
\text { NT3-B : Quartzite, gneiss, granite, basalt limestone sandstone, schist, phyllite, slate,sand, } \\
\text { silt and clay. } \\
\text { Boulder Conglomerate : Sub angular to sub rounded boulder cobble pebble of Quartzite, gneiss, } \\
\text { basic, schist, granite sandstone, Phyllite, slate, shale sand and silt. The fine matrix of sand, clay } \\
\text { and silt is cross bedded, laminated with cut and features } \\
\text { Boulder Bed: sub angular to angular, sub round hybrid and heterogeneous assorted rock } \\
\text { febric of Quartzite limestone, gneiss, granite, schist, , slate, sand, silt and clay. }\end{array}$ \\
\hline
\end{tabular}

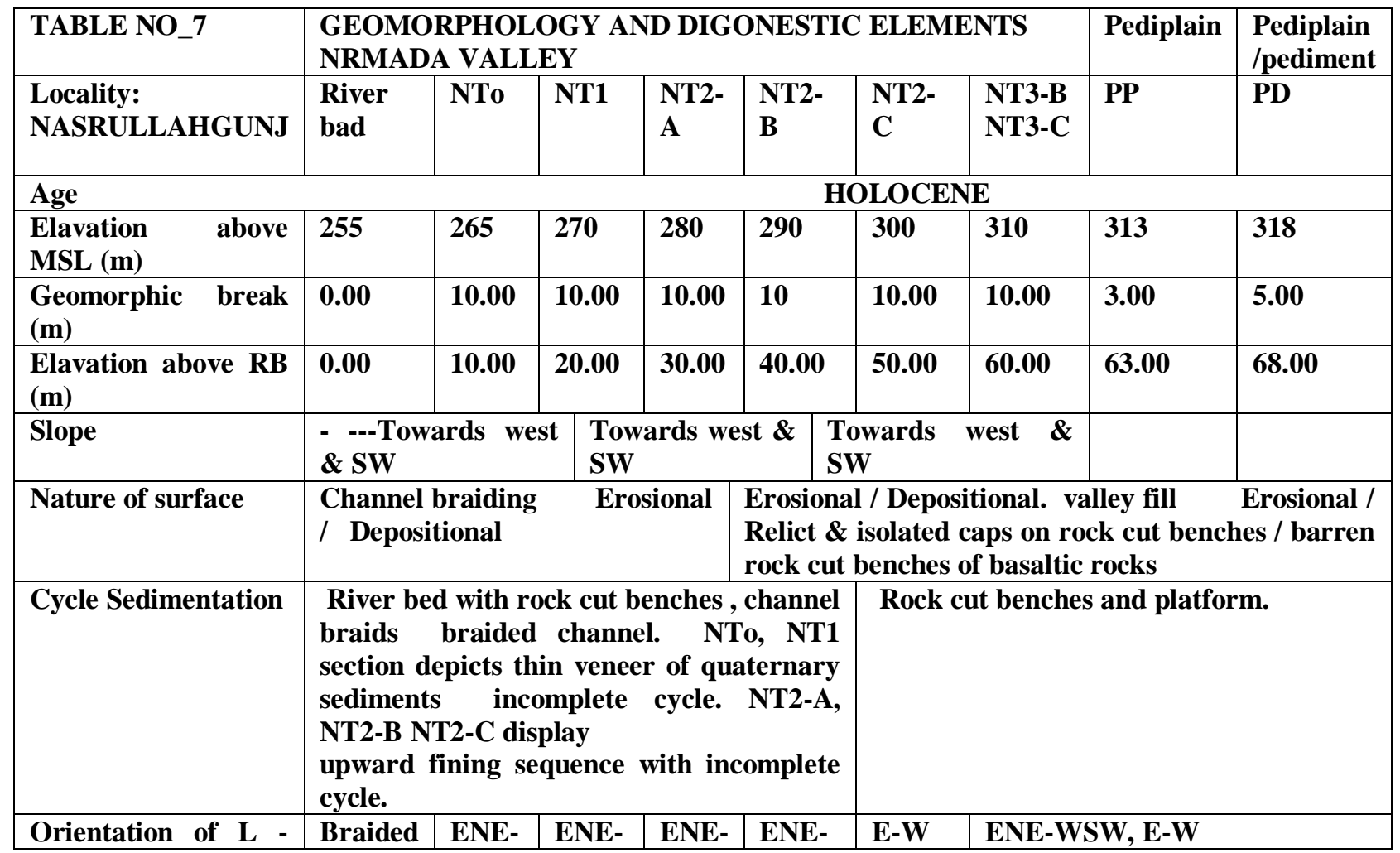




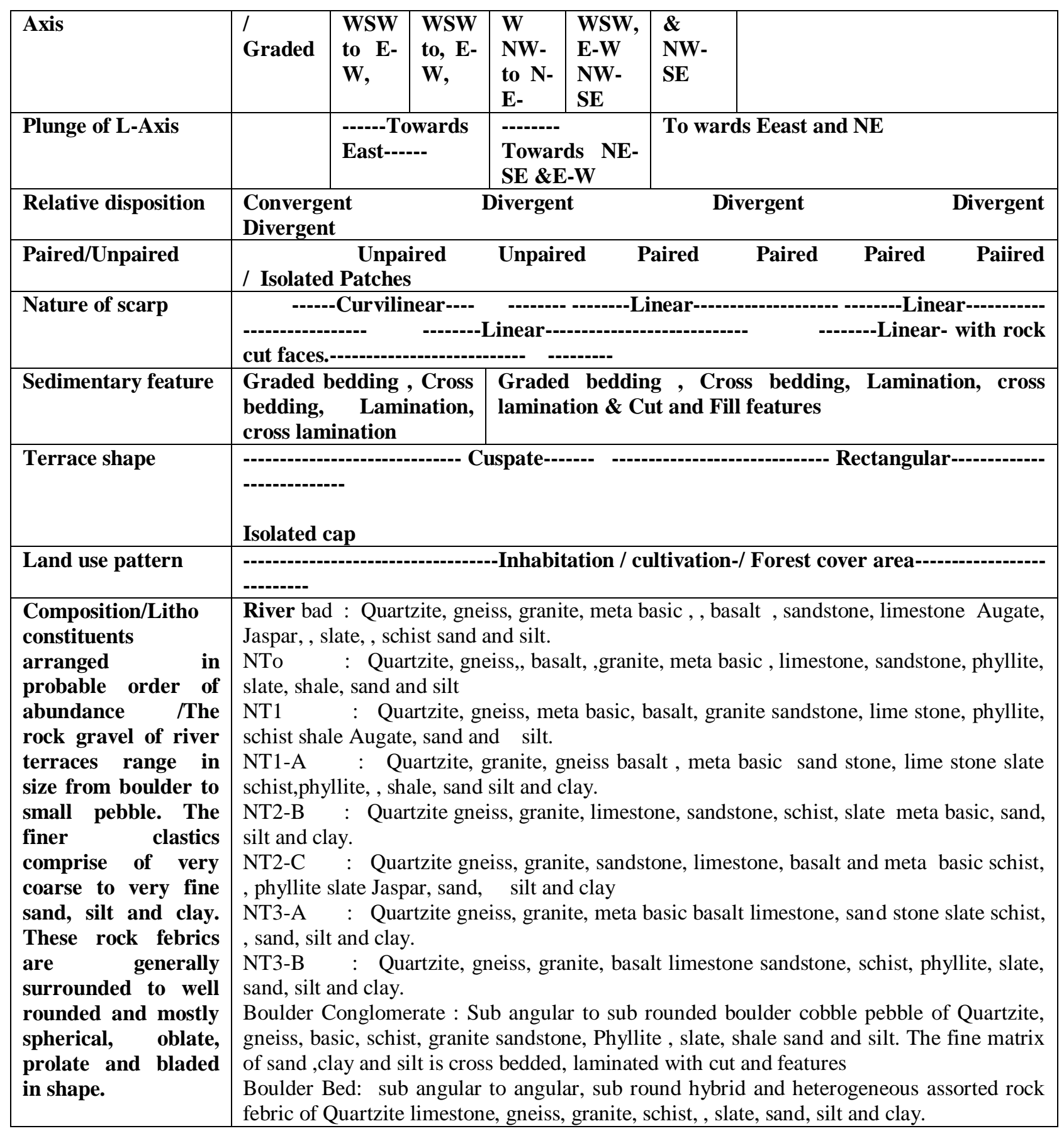




\section{Plate No.GH_1:-}
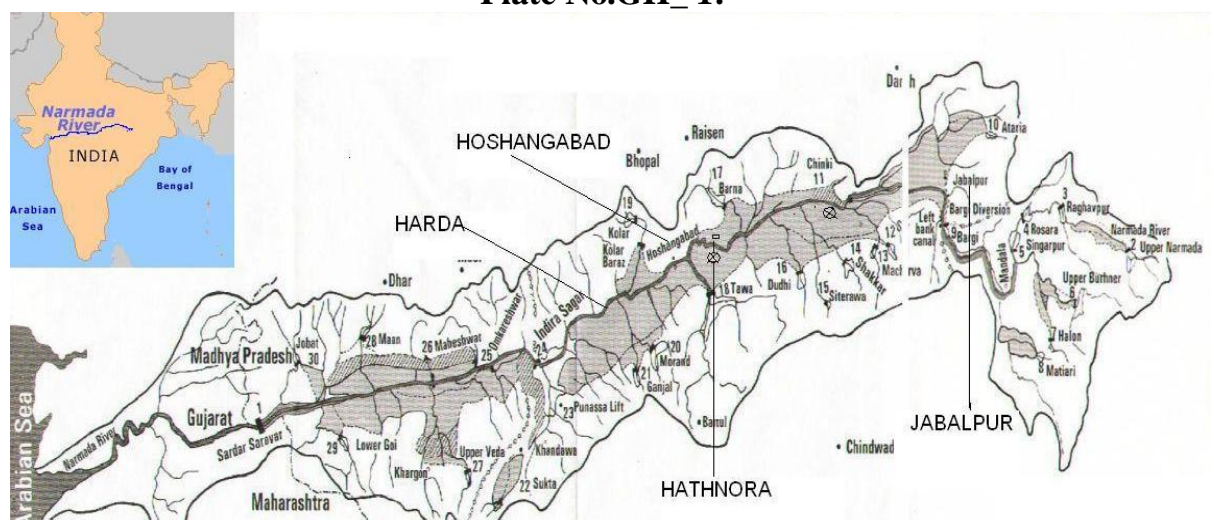

QLOCATION OF SAMPLES STUDIED

Plate NoGH_2:-

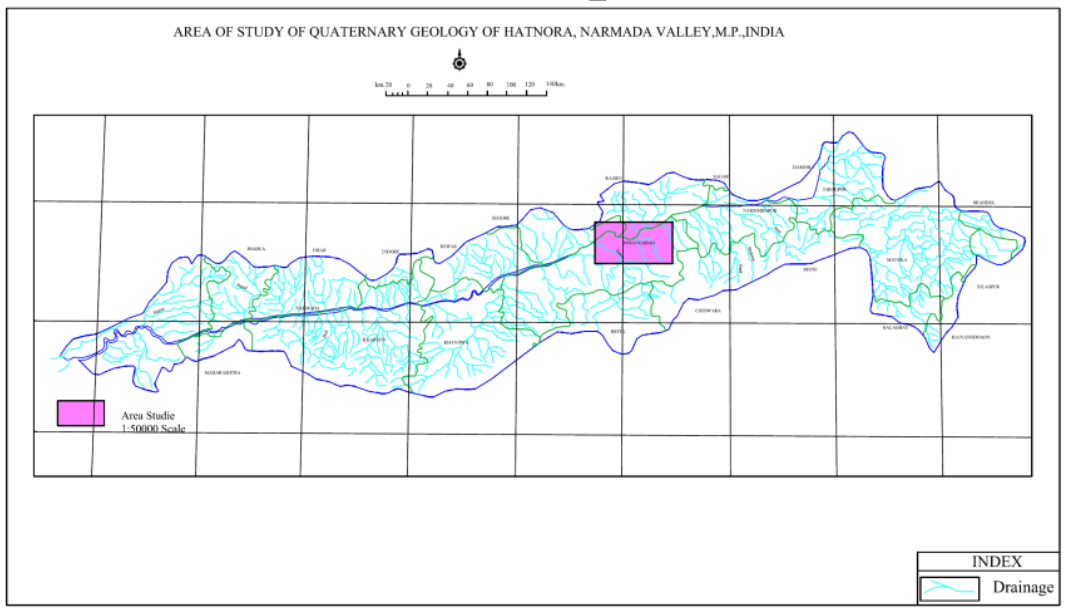

Plate NoGH_3:-

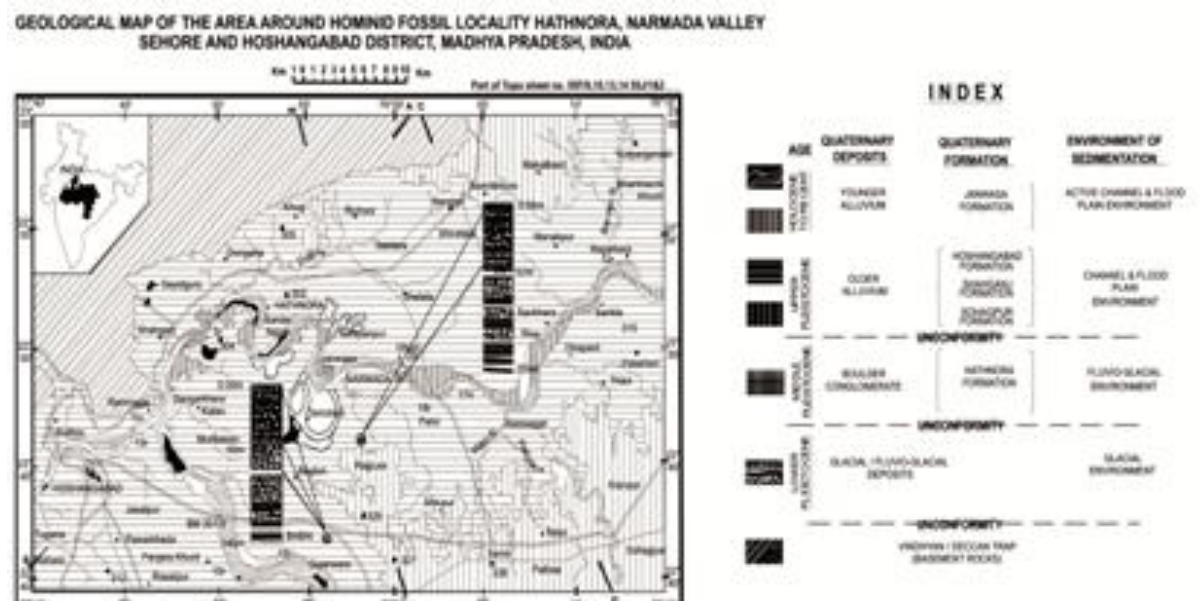




\section{Plate No GH_4:-}

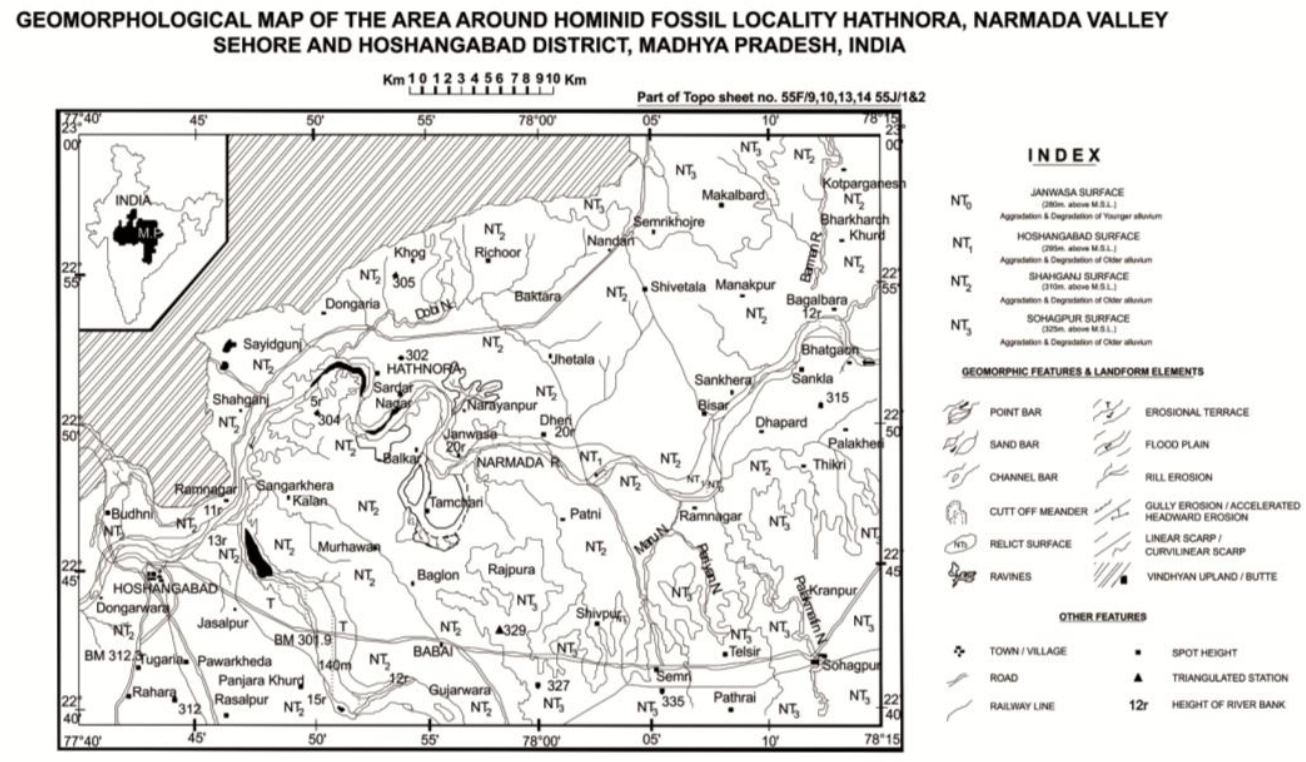

Plate No GH_5:-

CROSS SECTIONS OF QUATERNARY DEPOSITS OF NARMADA VALLEY, SEHORE \& HOSHANGABAD DISTRICTS, MADHYA PRADESH, INDIA

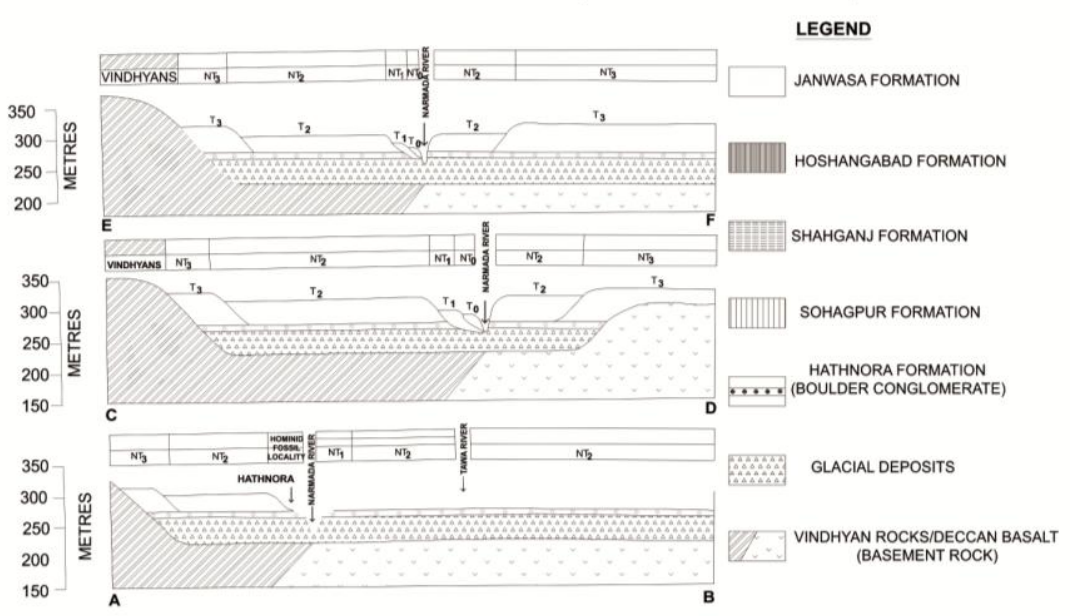


Plate No GH._6:-

LITHOSTRATIGRAPHIC SECTION OF QUATERNARY DEPOSITS OF HOMONID FOSSIL LOCALITY HATHNORA

NARMADA VALLEY, SEHORE \& HOSHANGABAD DISTRICTS, MADHYA PRADESH, INDIA

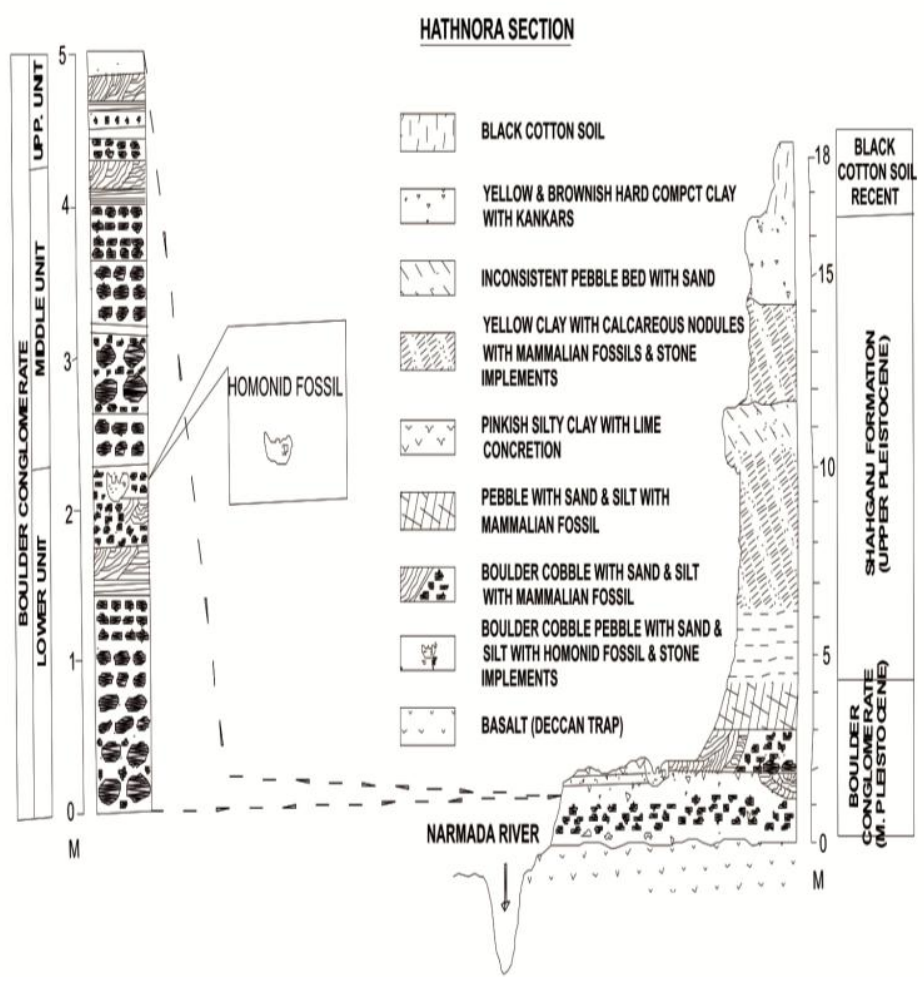

Plate No GH_7:-

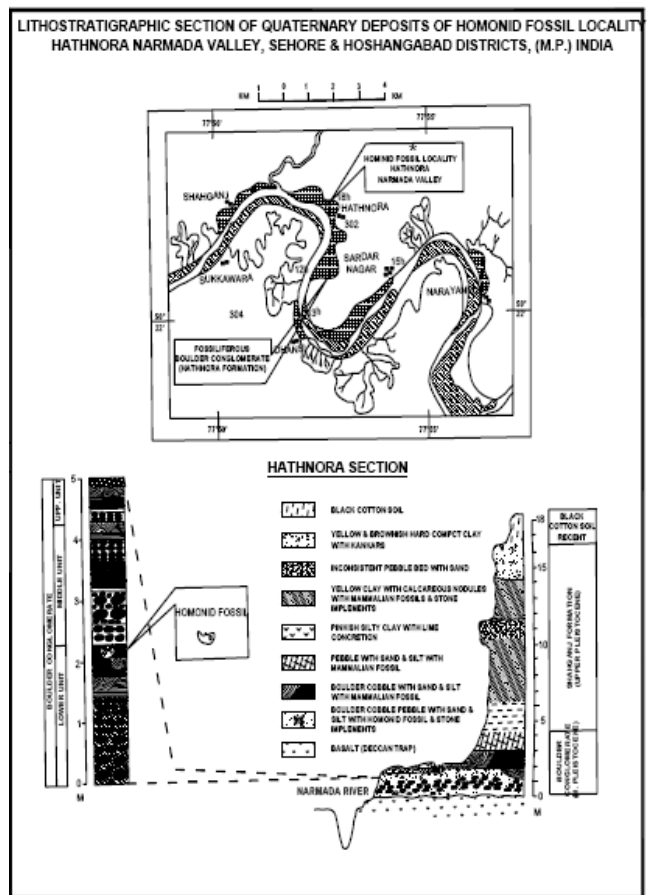




\section{Summary \& Conclusion:-}

Narmada River originates at Amarkantak at an elevation of about $1057 \mathrm{~m}$ above m.s.l. It descendeds from the mountainous tract traversing over a distance of $1280 \mathrm{~km}$ across the middle of the Indian sub-continent to join the Gulf of Cambay, near Baroda in Gujrat state. The area of study around Homonid locality Hathnora forms the part of central sector of Narmada, it is bound by Vindhyachal in the north and Satpura range to the south; the area in between these two upland is found to be ideal locus of sedimentation as witnessed by the presence of Quaternary landscape and multicyclic sequence of Quaternary terraces in the valley. The general elevation of Narmada alluvial plain varies between 00.00 to $65.00 \mathrm{~m}$ in lower Narmada and 65.00 to $95.00 \mathrm{~m}$ in upper Narmada valley above the sea level. The general gradient of this plain in this stretch is about $1 \mathrm{~m} / \mathrm{km}$ towards west.

The Narmada conspicuously has straight course is controlled by ENE_WSW to E_W lineament, is bounded by Vindhyan in the north and Satpura in the south it is exposed the repeated post erisional and depositional activities and subjected to anisotropic and asymmetric tectonic dislocation which has culminated diversified units and region which further undergone to process of tectonic evolution and chiseling of terrain by dynamic erosional and depositional activity resulting in and reshaping the terrain into various morphogenetic units and land form elements, re-configuration of drainage, topography, physiographic, erosional platform, planation surfaces, denudation ridges, structural units linear valleys, strike hills, valley gapes, escarpments and river terraces. The cumulative dynamics of structural deform, rinsing and sinking platform of Narmada has also manifested concealed cyclic mechanism of tectonics, seiesmicity, neosiesmic events and in surface manifestation. In addition the valley gapes and valley trenches provided ideal sites and platform for accumulation\& sedimentation.

The Narmada Rift valley formed a linear trench in the middle of Indian subcontinent was an ideal locus for accumulation of sediments. The rift trench is intruded by the dolerite and other mafic and siliceous dykes and sills along lineaments in different phases of tectonic deformation. The Quaternary sedimentation incepting from glacial activity, followed by fluvio-glacial, lacustrine and fluvial phase within the rinsing and sinking environment, block, faulting, uplifting, isolated domal up- lift, Neogene rifting, Quaternary sedimentation, rift-bound PliocenePleistocene rifting and volcanic activity specifically during glacial and fluvio-glacial phase are major component of the Quaternary period and tectonic processes of the Narmada Rift System which forms the base of quaternary deposits.

The glacial and fluvio-glacial deposits of Narmada unconformable overly the Vindhyan and the basaltic Deccan Trap rocks. The sediments consist of a Hetero-heterogeneous assemblage of sub-angular to angular, sub-rounded, unsorted, stratifiedrock fragments ranging from boulders to small pebbles, predominantly of quartzite, gneiss, sandstone, basalt, jasper, chart, gneiss, sandstone, basalt, chart, altered feldspar, ferruginous nodules, in a matrix of very coarse to very fine-sand, silt and clay. The sediments of glacial domain of Narmada occur between and average depth of about 320-265 below the surface and were deposited in glacial environments during Pleistocene time. These deposits are concealed under boulder conglomerate in the valley. The conglomerate bed that constituted the fossiliferous horizon of Narmada is sandwiched between older Alluvium and the glacio-fluvial bounder bed. This conglomerate bed is a very persistent marked horizon indicating a distance phase of sedimentation in the Narmada Valley. It is exposed in the bluff/scrap of Narmada around Sardar Nager, Hathnora, Surajgarh, Budhni, Hoshangabad, Khoksa, Tigharia, Demawar and Bhariya-Ghat at the base of terraces $\mathrm{NT}_{2}$ (Khan, 1984). The boulder conglomerate predominantly consists of sub-rounded to well-rounded boulder, cobble and pebble of quartzite, gneiss, sandstone, basalt, agate, jasper, chert, chalcedony tightly cemented in a matrix of sand and silt. These deposits identified between an average elevations of 245 to $300 \mathrm{~m}$ above m.s.l. the basal unit of boulder conglomerate identified is marked at an elevation of about $268 \mathrm{~m}$ above m.s.l, exposed on the northern bank of Narmada around Hathnora ( $\left.22^{\circ} 52^{\prime \prime} \mathrm{N}-77^{\circ} 52^{\prime} \mathrm{E}\right)$ at the depth of about $83 \mathrm{~m}$ in stratigraphic column of Quaternary sediments of Narmada.

The sediments of paleo-domain of Narmada conformably overlie the boulder conglomerate and represent the floodplain fluvial facies of the Narmada. The sediments of the fancies predominantly consist of clay silt and sand, discontinuous nodules and plates. The beds are horizontal, exhibit upward fining sequence typical of fluviatile deposits . This domain may be divided divided into three formations based on lithology, sediment assemblage, shape and size of rock clastics, relative disposition and diagnostic sedimentary characteristics. These formations are, viz. (i) Shohagpur, (ii) Shahganj, and (iii) Hoshangabad Formations respectively. These formations represent the sediments the complete sequence of Narmada deposited in channel and flood plain environments during Upper Pleistocene times. The lowest Sohagpur Formation is named after Sohagpur town. The unit occurs along the outer 
flanks of Narmada Valley bounded by Vindhyachal range to the north and Satpura to the south. It consists of sediments of paleo-domain of Narmada. It is represented by a thick sequence of clay, silt-sand and rock gravels.

In Narmada rift valley the quaternary sediments are accumulated in two section viz Jabalpur-Harda section and Guredhwar and bharouch section where as in other area Harda to Gurudeshwar section of valley rock cut terraces, rock cut platform and benches are notices which at many places over lie by caps and strips quaternary deposits representing the former level of valley floor of Narmada. The rock cut terraces and rock cut benches are time equivalent to NT1 to NT3 which have developed in Jabalpur-Harda and Gurudeshwar-Bharouche sections.Khan et.al (2016). The Quaternary events of the Narmada portys three prominent terraces and two sub terraces in these sections which are designated NT1 to NT3 and sub terraces NT2-A is NT2-B, NT2 B, besides NT2-C, NT3-A \& NT3-B besides NT-0 in the valley. They have been designed $\mathrm{NT}_{\mathrm{O}}$ to NT3, ( 280 to $400 \mathrm{~m}$ ), $\mathrm{NT}_{\mathrm{O}}$ being the low level terrace above the present-day course of the river, $\mathrm{NT}_{1}$-the younger terrace both of cyclic ad o cyclic nature. The $\mathrm{NT}_{3}$ terrace occurs as elongated strip and isolated caps and lenses along the margin of valley flanks has divergent relative disposition. These land forms indicate vigorous and abrupt incision of valley floor due to relatively \& repaid uplift of watershed area during Upper Pleistocene time. The NT1to $\mathrm{NT}_{2}$ are the major depositional terrace and have both convergent \& divergent mutual disposition with other terrace. These terraces further downstream have matched equivalents along the valley flanks, whereas in the up stream section the matched equivalents are rare. The conspicuous divergent relation of these terraces the valley reveals successive uplift of catchments area and consequential incision of valley floor and adjustment of base level of Narmada during Upper Pleistocene time.

The sequence of quaternary dposits depicts cyclic transitional environmental of the rift basins are caused by tectonic activities (uplift and subsidence), changes in relief, and climatic variations. The climatic changes in uplift, coupled with block faulting, rinsing and sinking platform, created basins unstable platform for the accumulations of thick lacustrine and fluvial sediments sequences with terrestrial and aquatic fossils. The evidence of the effects of tectonics on fauna and flora are distinct and its signatures on dislocation and concealing of fossiliferous horizons are uncontrolled and ill defined in the ecosystem in the valley during the Pliocene-Pleistocene periods. The boulder conglomerate which yielded the skull cap of Homo eructs in Narmada rift from Hathnora Sonakia (1984) remained only discovery of hominid fossil in last two and half decade due inconsistency and concealed nature of fosilifrous horizon due faulting, and subsidence of Quaternary blanket of Narmada rift system as such researcher and scientist failed to add any further knowledge to hominid discovery.in Narmada valley..

\section{References:-}

1. Acharya, S.K. and Basu, P.K. (1993): Toba ash on the Indian subcontinent and it simplication for correlation of late Pleistocene alluvium.Quaternary Research, No.-14. Pp10-14.

2. Acharyya, S. K., \& Basu, P. K. (1993). Toba ash on the Indian sub continent and its implications for the correlation of Late Pleistocene Al- Copyright $@ 20$

3. Acharyya, S.K., Kayal, J.R. and Roy, A. 1998 "Jabalpur Earthquake of May 22, 1997: Constraint from after Shock Study", Journal Geological Society of India, Vol. 51, pp. 295-304. Agarwai, B.N.P., Das, L.K., Chakraborty, K. and Sivaji, C.H. 1995 "Analysis of the Bouger anomaly over central India: A

4. Acharyya, S.K., Kayal, J.R. and Roy, A. 1998 "Jabalpur Earthquake of May 22, 1997: Constraint from L.K., Chakraborty, K. and Sivaji, C.H. 1995 "Analysis of the Bouger anomaly over central India: A

5. Acharyya, S.K., Kayal, J.R. and Roy, A. 2000, Tectono thermal history of the central India tectonic zone and reactivation of major faults, Jour.Geol.Soci. India 55,239-256.

6. Bhattaacharji,S; Chatterji,N; Wampler J.M. 1996 Zones of Narmada Tapti area activation and Deccan volcanisam: geochronological and geochemical evidences.In Deshmukh,S.S; nair ; k.K.K. (Eds)Deccan Baslts. Gondwana geological society, Nagpur PP 329-340

7. Chaube, V.D.(1970): The Narmada Son line thrust, the geat boundary fault along the southern margin of the Vidhyan basin, Central India, West Commomoration Volume, Today and Tommarow printers and publishers, Faridabad. Pp.420 - 438.

8. Folk R.L. and Ward W.C.1957"Brajors River Bar - A study in the of grain size parameters significance J.Sed. Pet., 27, 3-27

9. Jain, S.C., Nair, K.K.K.and Yedekar, D.B. (1991): Geology of Son-Narmad-Tapti lineament zone in Central India, in final report "on studies in phase II special project CRUMANSONATA" progress report (unpublished) Geol. Surr. Ind.

10. Jain, S.C., Yedekar, D.B.and Nair, K.K.K (1991): Central Indian shears Zone, a major Precambrain Crustal boundary. Jour.Geol Soc. India Vol.37. pp.521 - 531 . 
11. Jain, S.C., Yedekar, and D.B.and Nair, K.K.K (1991): Central Indian shears Zone, a major Precambrain Crustal boundary. Jour.Geol Soc. India Vol.37. pp.521 - 531.

12. Jain, S.C., Nair, K.K.K.and Yedekar, D.B.(1993): Geology of Son-Narmada-Tapti lineament zone in Central India, In final report "on studies in phase II special project CRUMANSONATA" progress report (unpublished) Geol. Surr. Ind.

13. Khan A.A. \& Balchandran,V (1974-75) Records Volume109 of Gelogical survey Of India partI,pp.59

14. Khan A.A. 1984 Geology of Geomorphological studies in parts of Narmada Basin, Sehore Dist. Of M.P. GeolSurv. Of India Progress Report (Unpublished).

15. Khan, A.A. \& Banerjee, S.N. (1984) Geology and Geomorphological studies in the parts of Narmada Basin, Sehore district of M.P. Un Pub. Report. Geol. Surv. India.

16. Khan, A.A. (1984) Geological and Geomorphological studies around Tapti-Vagher confluence district Jalgaon, Maharashtra. Geol, Surv. India Rec. V.113 pt 6 pp 99-109

17. Khan A.A. and Bajerjee, S.N. 1985: Geomorphological and geological studies of Quaternary sediments in collaboration with project Crumansonata in parts of the Narmada basin, Sehore, Dewas and Hoshangabad districts unpublished Geol. Surv. Ind. Progress Report.

18. Khan, A.A. (1990) Geomorphology of Narmada Valley Of Jabalpur_Handia Section Unpublished G.S.I Note.

19. Khan, A.A., and Rahate, D.N (1990-91 \& 1991-92) Geological and Geomor -phological studies in parts of Narmada Basin) parts Hoshangabad and Narshingpur district, M.P. Geol. Surv. Of India Unpublished Progress Report.

20. Khan, A.A.( 1991).Geological studies of Harda - Barwaha basin in parts of Dewas, Sehore, Hoshangabad and Khandwa districts with the Aid of Satellite imagery and Remote Sensing Techniques, Geol. Surv. Ind, Rec. Vol; 126 pt-6

21. Khan, A.A, Rahate, D.N. (1991) Volcanic Ash from Quaternary deposits of Narmada Valley Central India. Proceed, of $78^{\text {th }}$ session of Indian Sci. Cong. Association. (Abstract) pt. III pp 28-29

22. Khan, A. A, Rahate, D.N, Fahim, M \& Banerjee, S.N.( 1991 ) Evaluation of Quaternary terrace of lower Narmada valley, Districts Sehore and Hoshangabad, Madhya Pradesh

23. Khan, A.A., Rahate, D.N; Shah; (1991) M.R. and Fahim; M. volcanic Ash from Quaternary deposits of Narmada valley central India. Indian science Congress 1991

24. Khan, A., \&Sonakia, A. (1992). Quaternary deposits of Narmada with special reference to the hominid fossil. Journal of the Geological Society of India, 39, 147-154.

25. Khan, A.A, Rahate, D.N,, FAHIM, M. and Banarjee,S.N ( 1992) Evaluation of Geology and Geomorphology in Central Narmada Valley ( Districts Sehore and Hoshangabad, Madhya Pradesh ) Scientific Publishers, Jodhpur.

26. Khan, A.A; Rahate D.N, Fahim, M. and Banarjee, S.N. (1992): Evaluation of Geology and Geomorphology in Central Narmada Valley (Districts Sehore and Hoshangabad, Madhya Pradesh) Scientific Publishers, Jodhpur

27. Khan A.A. 1994 Geological and Geomorphological studies around Tapti-Vagher confluence district JaloaonMaharastra, Geol. Surv. Of India, Rev. Vol. 113 pt. 6 pp $99-109$.

28. Khan A.A. \& Maria Aziz (2012)"Homo erectus On Unified Quaternary Platform in India and China a Correlation \& Sequential Analysis". Status Published Research Scapes International Journal Vol I, Issue IV October -December 2012. (ISSN: 2277-7792)

29. Khan. A.A. \& Aziz, Maria (2012) "Homo Erectus \& Homo Sapiens In Spectrum Of Volcanic Ecology, Narmada Valley (M.P) India"Status Published Research Scapes International Multidisciplinary Journal VolI, Issue III July-September 2012

30. Khan, A.A. \& Aziz; Maria (2013) Homo Erectus \& Homo Sapien in Spectrum of Volcanic Ecology, Narmada valley (M.P.) India Research scapes vol. i issue -4 pp-161 -178

31. Khan A.A; \& Joshi O.P. ( 2014) Geology Lithostratigraphy And Correlation of Basaltic Lava Flows of Parts of Western Madhay Pradesh With Special Reference To Megacryst Bearing Horizons And Geotechnical Aspects For Heavy Engineerging Structures

32. Khan, A.A \& Aziz, Maria (2014-15) Tectonics Evolution, Quaternary Sedimentation, And The Paleoanthropological Record InThe Narmada Rift System (m.p.) Central India Khan*, A.A. Aziz, Maria International Journal for Research and Technological Sciences Vol. 1, Issue 1 (2014) 91-93 ISSN -2349-0667.

33. Khan A.A. \& Aziz, Maria (2015) Quaternary Tectonics \& Sedimentation in Narmada Rift Valley, With Special Reference to Garudeshwar and Bharuch Section Gujarat State India, ISSN 2320-5407 International Journal of Advanced Research (2015), Volume 3, Issue 3, 430-457 430 Journal homepage: http://www. journalijar. com.

34. Khan, A.A. \& Aziz; Maria (2014-2015). Quaternary volcanic Eruption Toba Ash fall its impact on Environment of late Pleistocene Hominines in Indian subcontinent with Special Reference to Narmada Valley. International 
journal of Research in Technological sciences vol.1, Issue 2 \& Vol-2 issue-1 July -January 2014 January-June 2015 PP1-18 (ISSN-2349-0667)

35. Khan, A.A. Aziz; Maria (2015) A critical analysis of statistical parameters of quaternary deposit of Hominid locality, Hathnora, Narmada valley, distirctsehore (M.P), India Jour. Of Agriculture, Foresty and Environment al Science Vol.IIssue.I July -Aug 2015 .I pp 17-29 ISSN 2454-2792.

36. Khan A.A. \& Aziz, Maria (2016) Heavy Minerals assemblage of quaternary column of hominid locality Hathnora, Nnarmada valley district SehoreM.P India. ISSN 2320-5407 International Journal of Advanced Research (2016), Volume 4, Issue 7, 1748-1780 Journal homepage: http://www. journalijar. com.

37. Khan A.A. Maria Aziz. (2016) Quaternary tectonics \& geomoprhic evolution of Narmada vally, its impact on tracing the remains of Homo erectus and other quaternary fauna \& flora. ISSN 2320-5407 International Journal of Advanced Research (2016),

38. Mishra, P.S., Venkatraman, N.V., Roy, Abhinaba and Tiwari, M.P., 1999: Seismotectonics evaluation of Quaternary sedimentary basins yoked with Satpura horst. Gondwana Geological magazine, Special Vol. 4, pp. $81-$

39. Roy, A.K. 1971 Geology and Ground Water Resources of Narmada Valley Bult of Geol

40. Ravi Shankar, 1987 : History and status of geothermal exploration in the Central Region (M.P. \& Maharashtra). Rao, Geol. Surv. Ind., 115, pt. 6, pp. 7-29.

41. Sonakia A. 1984 The Skull Cap of Early man and associated mammalian fauna from Narmada Valley alluvium Hoshangabad area. Madhya Pradesh, India Rec. GeolSurv. India Vol. 113, Pt. 6 pp 159-172

42. Tiwari, M.P.and Bhai.H.Y., 1997: Quaternay stratigraphy of the Narmada valley, Geol. Surv. Ind., Special Publication No.46, pp. 33-63 Maharashtra and M.P. Rec. Geol. Surv. Ind., Vol. 114, Pt.6 pp.71-81. 